\title{
Staphylococcus aureus hemolysins, bi-component leukocidins, and cytolytic peptides: a redundant arsenal of membrane-damaging virulence factors?
}

\author{
François Vandenesch ${ }^{1,2,3}$, G. Lina ${ }^{1,2,3}$ and Thomas Henry ${ }^{1,2 *}$ \\ "Bacterial Pathogenesis and Innate Immunity Laboratory, INSERM U851 "Immunity, Infection and Vaccination," Lyon, France \\ 2 Université de Lyon, Lyon, France \\ ${ }^{3}$ Hospices Civils de Lyon, Lyon, France
}

\section{Edited by:}

Martin John McGavin, University of Western Ontario, Canada

Reviewed by:

Tammy Kielian, University of Nebraska Medical Center, USA Juliane Bubeck Wardenburg, University of Chicago, USA

\section{*Correspondence:}

François Vandenesch and Thomas

Henry, Bacterial Pathogenesis and Innate Immunity Laboratory, INSERM

U851, 21, Avenue Tony Garnier, 69365 Lyon Cedex, France.

e-mail: francois.vandenesch@univlyon1.fr; thomas.henry@inserm.fr
One key aspect of the virulence of Staphylococcus aureus lies in its ability to target the host cell membrane with a large number of membrane-damaging toxins and peptides. In this review, we describe the hemolysins, the bi-component leukocidins (which include the Panton Valentine leukocidin, LukAB/GH, and LukED), and the cytolytic peptides (phenol soluble modulins). While at first glance, all of these factors might appear redundant, it is now clear that some of these factors play specific roles in certain $S$. aureus life stages and diseases or target specific cell types or species. In this review, we present an update of the literature on toxin receptors and their cell type and species specificities. Furthermore, we review epidemiological studies and animal models illustrating the role of these membranedamaging factors in various diseases. Finally, we emphasize the interplay of these factors with the host immune system and highlight all their non-lytic functions.

Keywords: Staphylococcus aureus, hemolysin, leukocidin, Panton Valentine leukocidin, PSM, inflammasome, pore-forming toxin, neutrophil

\section{INTRODUCTION}

Staphylococcus aureus is both a commensal bacterium found in about $30 \%$ of the healthy population and is one of the most virulent bacterial pathogens. The ability of this bacterium to cause diseases is associated with a large number of virulence factors allowing colonization and persistence, dissemination within the host, and evasion of the immune system. The set of virulence factors required to cause disease is likely to be highly dependent on the site of infection [e.g., skin and soft tissues infections (SSTI) versus infective endocarditis]. Particularly, S. aureus secretes numerous exotoxins, including a group of polypeptides capable of damaging the host cell plasma membrane. These polypeptides include pore-forming toxins [PFT: $\alpha$-hemolysin and the bi-component leukocidins $\gamma$-hemolysin, the Panton Valentine leukocidin (PVL), LukED, and LukGH/AB], $\beta$-hemolysin (a neutral sphingomyelinase), and the phenol soluble modulins (PSMs, a family of small amphipathic peptides). While leukotoxic and hemolytic activities (the ability to lyse leukocytes and red blood cells, respectively) in S. aureus supernatant was described more than a century ago (Julianelle, 1922; Panton and Valentine, 1932), our understanding of the specific and physiological roles of the various toxins remains far from complete. The receptor for $\alpha$ hemolysin, one of the most studied virulence factors since its discovery in the beginning of the past century, has only been identified recently, leading to novel important insights concerning the function of this toxin (Wilke and Bubeck Wardenburg, 2010; Inoshima et al., 2011). Furthermore, several highly expressed membrane-damaging (poly)peptides have been discovered in the past 5 years (Queck et al., 2009; Ventura et al., 2010; Dumont et al.,
2011) highlighting both the gaps in knowledge and the extensive research efforts aimed at uncovering the function of these membrane-damaging toxins. The goal of this review is to give an update on the different membrane-damaging toxins and their role in S. aureus-mediated diseases. The molecular mechanisms of pore formation, which have been reviewed before (Kaneko and Kamio, 2004; Verdon et al., 2009), are not detailed here. Instead, we focus on understanding the interactions between these virulence factors and various host cells from different species and review their roles in S. aureus-mediated diseases. Furthermore, we describe the interplay between the innate immune system, which has evolved to sense membrane damage, and these virulence factors, several of which specifically target innate immune cells. Finally, we present the moonlighting activities of these toxins and discuss how these activities could be more relevant than the toxins' lytic activity in colonization and diseases.

\section{OVERVIEW OF THE DIFFERENT CLASSES OF MEMBRANE-DAMAGING (POLY)PEPTIDES $\alpha$-HEMOLYSIN}

$\alpha$-Hemolysin is the most characterized virulence factor of $S$. aureus. Upon binding to the cell surface, $\alpha$-hemolysin monomers assemble into a homoheptamer, forming a prepore. The prepore subsequently transitions to a mature $\beta$-barrel transmembrane pore (Bhakdi and Tranum-Jensen, 1991), thereby leading to the formation of a 14- $\AA$ diameter aqueous channel (Song et al., 1996). This pore allows the transport of molecules smaller than $2 \mathrm{kD}$ (Menestrina, 1986), such as $\mathrm{K}^{+}$and $\mathrm{Ca}^{2+}$ ions, leading to necrotic death of the target cell. 


\section{$\gamma$-HEMOLYSIN AND BI-COMPONENT LEUKOCIDINS}

Staphylococcus aureus possesses several other PFTs in addition to $\alpha$ hemolysin. In contrast to $\alpha$-hemolysin, the formation of a mature pore by these other PFTs involves two polypeptides that have been named S (slow) and F (fast) based on their electrophoretic mobility. The different $S$. aureus bi-component PFTs share significant homology (see Supplemental Figure S3 in Dumont et al., 2011). The PFTs include (i) $\gamma$-hemolysin corresponding to two combinations of a $\mathrm{S}$ component ( $\mathrm{HlgA}$ or $\mathrm{HlgC}$ ) with a $\mathrm{F}$ component (HlgB); (ii) the PVL (Panton and Valentine, 1932), made of LukSPV and LukF-PV; (iii) LukED (Gravet et al., 1998; Morinaga et al., 2003); (iv) LukGH (Ventura et al., 2010), also known as LukAB (Dumont et al., 2011). The structure of these bi-component toxins (Olson et al., 1999; Pedelacq et al., 1999; Guillet et al., 2004) and their mechanism of pore formation have been mostly studied using $\gamma$-hemolysin and PVL, but are thought to be similar for all of the toxins. Each water-soluble component binds sequentially to the cell surface as a monomer before oligomerizing into a prepore formed by four $\mathrm{S}$ components alternatively arranged with four $\mathrm{F}$ components. The mature hetero-octamer forms a transmembrane $\beta$-barrel pore across the plasma membrane, leading to host cell lysis. The bi-component toxins are largely considered to be secreted proteins. LukGH/AB was identified both as a secreted protein in the extracellular medium and as one of the predominant surface protein of $S$. aureus at the late exponential phase of growth (Ventura et al., 2010). Surface association of this leukotoxin might be involved in targeting immune cells when they are in direct contact with the bacterium, such as during phagocytosis.

\section{$\beta$-HEMOLYSIN}

In contrast to the PFTs, the $\beta$-hemolysin does not form pores in the plasma cell membrane but instead is a neutral sphingomyelinase hydrolysing sphingomyelin, which is a plasma membrane lipid. $\beta$ hemolysin's enzymatic activity is required for its hemolytic activity (Huseby et al., 2007; Ira and Johnston, 2008). $\beta$-hemolysin lysis of red blood cells is only observed after the cells are switched to low temperature, suggesting that the lytic activity of $\beta$-hemolysin is not as efficient as that of other hemolysins, at least toward erythrocytes. $\beta$-hemolysin digests sphingomyelin into ceramide and phosphorylcholine (Doery et al., 1963). The mechanism leading to cytotoxicity is still poorly understood. Sphingomyelin is enriched in lipidordered membrane microdomains with high content in cholesterol. Sphingomyelinase treatment of synthetic lipid bilayers leads to aggregation of cholesterol-rich microdomains (Ira and Johnston, 2008), suggesting that cell death may result from the modification of host cell plasma membrane fluidity and destabilization of the bilayer structure. Alternatively, cell death might result from the formation of large ceramide-rich signaling platforms.

\section{$\delta$-HEMOLYSIN AND PSMs}

This class of membrane-damaging peptides was identified over 60 years ago with the purification of $\delta$-hemolysin (Wiseman, 1975). $\delta$-hemolysin is a small amphipathic (one hydrophobic and one hydrophilic side) peptide (26 AA) with an $\alpha$-helix structure. Three different mechanisms (reviewed in Verdon et al., 2009) have been proposed to explain its hemolytic activity. Briefly, $\delta$-hemolysin could (i) bind to the cell surface and aggregate to form transmembrane pores; (ii) bind to the cell surface and affect the membrane curvature, thereby destabilizing the plasma membrane; or (iii) at high concentration, act as a detergent to solubilize the membrane. Recently, this family of small cytotoxic amphipathic peptides has grown with the identification of new peptides termed PSM, first in S. epidermidis (Mehlin et al., 1999) and subsequently in S. aureus (Wang et al., 2007; Queck et al., 2009). Two families of PSMs have been described based on their length (Wang et al., 2007). PSM $\alpha$, which include $\delta$-hemolysin, PSM $\alpha 1-4$, and PSMmec (Queck et al., 2009), are 20-26 aminoacids long. In contrast, PSM $\beta 1$ and PSM $\beta 2$ are 44 aminoacids long.

\section{RECEPTORS, CELL, AND SPECIES SPECIFICITIES}

Comparison of toxin activity between different studies conducted using different cell types can be misleading, due to potential differences in specific activities or to the presence of contaminants linked to both the source of toxin (produced in S. aureus or in E. coli) and the nature of the purification process (see Craven et al., 2009). Keeping this possibility in mind, we review the data from the literature regarding toxin activity toward various cell types below and in Table 1.

\section{$\alpha$-HEMOLYSIN}

$\alpha$-hemolysin displays species- and cell type specificity. While rabbit erythrocytes are highly sensitive to $\alpha$-hemolysin-mediated lysis, human erythrocytes are much less sensitive. Furthermore, while human lymphocytes and monocytes are $\alpha$-hemolysin-susceptible cells (maximum lysis at $100 \mathrm{ng} / \mathrm{ml}$ ), granulocytes are highly resistant to $\alpha$-hemolysin lysis (no lysis at $10 \mu \mathrm{g} / \mathrm{ml}$; Bhakdi et al., 1989; Valeva et al., 1997; Loffler et al., 2010). Similarly, lysis of human lung epithelial cells (A549) is only observed at high $\alpha$-hemolysin concentrations $(1 \mu \mathrm{M}$ id $30 \mu \mathrm{g} / \mathrm{ml}$; Rose et al., 2002; Wilke and Bubeck Wardenburg, 2010). The cell type and species specificities suggest the presence of a specific high affinity receptor (Bhakdi and Tranum-Jensen, 1991). Crystal structure of $\alpha$-hemolysin bound to phosphocholine (Galdiero and Gouaux, 2004) validated early studies showing a requirement for phosphatidylcholine in generating $\alpha$-hemolysin lytic activity against liposomes (Watanabe et al., 1987). However, the presence of phosphatidylcholine as a sole receptor cannot explain the low number of high affinity and saturable binding sites observed in rabbit erythrocytes. Valeva et al. (2006) showed that clustering of phosphocholine heads into lipid rafts (microdomains) could create high affinity binding sites. In agreement with this study, cholesterol depletion or sphingomyelinase treatment, which affect lipid rafts decreases the clustering of phosphatidylcholine lipids and abolishes the high affinity binding of $\alpha$-hemolysin to rabbit erythrocytes. Recently, a biochemical approach led to the identification of A Disintegrin and Metalloproteinase Domain-containing protein 10 (ADAM10) as a $\alpha$-hemolysin-interacting protein (Wilke and Bubeck Wardenburg, 2010). $\alpha$-Hemolysin binding to different cell types correlates with ADAM10 expression. Furthermore, knock-down of ADAM10 gene expression in A549 cells decreases both $\alpha$-hemolysin binding and lytic activity. ADAM10 is highly expressed in A549 cells and rabbit erythrocytes but not on human erythrocytes. To the best of our knowledge, the abundance of ADAM10 on human granulocytes has not been investigated. The resistance of 
Table 1 | Species and cell type specificities of the various hemolysins, bi-component leukocidins, and PSMs.

\begin{tabular}{|c|c|c|c|}
\hline Toxin/peptide & Target cell ( $\%$ lysis) & Dose & Reference \\
\hline \multirow[t]{5}{*}{$\alpha$-Hemolysin } & Human lymphocyte (80\%) & $100 \mathrm{ng} / \mathrm{ml}$ & Valeva et al. (1997) \\
\hline & $\begin{array}{l}\text { Jurkat cells and peripheral blood monocytes } \\
(0 \% \text { : resistant })\end{array}$ & $100 \mathrm{ng} / \mathrm{ml}$ up to $20 \mu \mathrm{g} / \mathrm{ml}$ & Bantel et al. (2001), Bhakdi et al. (1989) \\
\hline & $\begin{array}{l}\text { Human granulocytes/neutrophils (0\%: } \\
\text { resistant) }\end{array}$ & $10 \mu \mathrm{g} / \mathrm{ml}$ up to $20 \mu \mathrm{g} / \mathrm{ml}$ & Valeva et al. (1997), Loffler et al. (2010), Bhakdi et al. (1989) \\
\hline & Human monocytes (90\%) & $80 \mathrm{ng} / \mathrm{ml}$ & Bhakdi et al. (1989), Bantel et al. (2001) \\
\hline & A549 (40\%) & $375 \mathrm{nM}(10 \mu \mathrm{g} / \mathrm{ml})$ & Wilke and Bubeck Wardenburg (2010) \\
\hline \multirow[t]{5}{*}{ PVL } & Murine alveolar macrophages ${ }^{1}$ & $(280 \mathrm{nM}) 10 \mu \mathrm{g} / \mathrm{ml}$ & Ziebandt et al. (2010) \\
\hline & Human macrophages (90\%) & $100 \mathrm{ng} / \mathrm{ml}$ & Perret et al. (in press) \\
\hline & Human neutrophils (90\%) & $80 \mathrm{ng} / \mathrm{ml}$ & Loffler et al. (2010) \\
\hline & Murine neutrophils (20\%) & $40 \mu \mathrm{g} / \mathrm{ml}$ & Loffler et al. (2010) \\
\hline & Rabbit neutrophils (90\%) & $60 \mathrm{ng} / \mathrm{ml}$ & Loffler et al. (2010) \\
\hline LukAB/GH & Human polymorphonuclear cells (60\%) & $2.5 \mu \mathrm{g} / \mathrm{ml}$ & Dumont et al. (2011) \\
\hline LukED & Murine peritoneal exudate cells $(60 \%)^{2}$ & $2.5 \mu \mathrm{g} / \mathrm{ml}$ & Alonzo et al. (2012) \\
\hline \multirow[t]{7}{*}{$\beta$-Hemolysin } & Sheep erythrocyte $(50 \%)^{3}$ & $500 \mathrm{ng} / \mathrm{ml}$ & Tajima et al. (2009) \\
\hline & HUVEC (resistant) ${ }^{4}$ & $1 \mu \mathrm{g} / \mathrm{ml}$ & Tajima et al. (2009) \\
\hline & Human fibroblast (resistant) & $1 \mu \mathrm{g} / \mathrm{ml}(5 \mu \mathrm{g} / \mathrm{ml})$ & Walev et al. (1996) \\
\hline & T lymphocyte (resistant) & $1 \mu \mathrm{g} / \mathrm{ml}(5 \mu \mathrm{g} / \mathrm{ml})$ & Walev et al. (1996) \\
\hline & Granulocyte (resistant) & $1 \mu \mathrm{g} / \mathrm{ml}(5 \mu \mathrm{g} / \mathrm{ml})$ & Walev et al. (1996) \\
\hline & Monocyte (50\%) & $0.001 \mu \mathrm{g} / \mathrm{ml}(5 \mathrm{ng} / \mathrm{ml})$ & Walev et al. (1996) \\
\hline & Lymphocyte (NA) ${ }^{5}$ & $10 \mu \mathrm{g} / \mathrm{ml}$ & Huseby et al. (2007) \\
\hline \multirow[t]{2}{*}{$\delta$-Hemolysin } & HeLa & 0.5 Hemolytic units/ml & Thelestam et al. (1973) \\
\hline & Human neutrophils (5\%) & $10 \mu \mathrm{g} / \mathrm{ml}$ & Wang et al. (2007) \\
\hline PSM $\alpha 1$ & Human neutrophils (7.5\%) & $10 \mu \mathrm{g} / \mathrm{ml}$ & Wang et al. (2007) \\
\hline PSM $\alpha 2$ & Human neutrophils (10\%) & $10 \mu \mathrm{g} / \mathrm{ml}$ & Wang et al. (2007) \\
\hline $\mathrm{PSM} \alpha 3$ & Human neutrophils (60\%) & $10 \mu \mathrm{g} / \mathrm{ml}$ & Wang et al. (2007) \\
\hline PSM-mec & Human neutrophils (12\%) & $50 \mu \mathrm{g} / \mathrm{ml}$ & Queck et al. (2009) \\
\hline PSM $\beta 1$ & Human blood (weak) & $1 \mu \mathrm{g} / \mathrm{ml}$ & Cheung et al. (2011) \\
\hline
\end{tabular}

${ }^{1}$ Death monitored at $16 \mathrm{~h}$ post-intoxication.

${ }^{2}$ PEC were isolated from mice injected with S. aureus Newman strain $16 \mathrm{~h}$ before and intoxicated ex vivo with recombinant LukED.

${ }^{3}$ Hot-cold hemolysis.

${ }^{4}$ Human umbilical vein endothelial cells.

${ }^{5}$ Inhibition of proliferation.

human granulocytes to $\alpha$-hemolysin does not seem to be due to differences in $\alpha$-hemolysin binding affinity but rather to the absence of insertion of the heptamer into the plasma membrane (Valeva et al., 1997). While this granulocyte resistance has been speculated to be associated with a specific response-inhibiting membrane insertion of pore-forming toxins (Valeva et al., 1997), the resistance might instead be linked to the absence of a coreceptor. Indeed, scanning $\alpha$-hemolysin sequence for eukaryotic domains revealed a nine aminoacid motif resembling a caveolin1-binding domain (Pany et al., 2004). Recombinant caveolin-1 added exogenously inhibits $\alpha$-hemolysin-mediated red blood cell lysis, and $\alpha$-hemolysin with a mutated caveolin- 1 recognition site is inactive, due to impaired heptamerization on the cell surface (Pany et al., 2004). While ADAM10 could be involved in the first binding event, caveolin-1 might trigger a conformational change allowing $\alpha$-hemolysin insertion into membrane. The relevance of caveolin-1-binding still needs to be thoroughly investigated, but caveolin-1 appears to be highly expressed in the lung and in epithelial cells (www.biogps.org). The expression patterns of caveolin-1 and ADAM10 might thus explain the cell and the species specificity observed for $\alpha$-hemolysin. Furthermore, caveolae are caveolin-1, cholesterol and sphingomyelin-rich microdomains at the plasma membrane (Lajoie and Nabi, 2007). $\alpha$-Hemolysin treatment relocalizes ADAM10 to caveolin-1 positive domains (Wilke and Bubeck Wardenburg, 2010). The connection between phosphatidylcholine clusters, lipid rafts, caveolin-1, and ADAM10 remains unclear. Sequential binding to those different receptors might be important to coordinate conformational changes and $\alpha$-hemolysin oligomerization to trigger cell-specific lysis or localized ADAM10 activation in E-cadherin-containing caveolae (see below).

\section{$\boldsymbol{\gamma}$-HEMOLYSIN AND BI-COMPONENT TOXINS}

$\gamma$-Hemolysin and, to a lesser extent, LukED are hemolytic to rabbit erythrocytes (Morinaga et al., 2003). PVL is non-hemolytic. To our knowledge, there is no report of hemolytic activity for LukAB/GH. While $\gamma$-hemolysin and PVL are highly cytotoxic toward human neutrophils (action at $10 \mathrm{ng} / \mathrm{ml}$ ), LukAB/GH is only cytotoxic 
toward the same cells at a 100-fold higher concentration (Dumont et al., 2011). No biological activity had been assigned to LukED for over 10 years (Gravet et al., 1998) although one variant, named $\operatorname{LukE}_{\mathrm{v}}-\mathrm{LukD}_{\mathrm{v}}$, was shown to display high leukotoxicity toward human neutrophils (Morinaga et al., 2003). Recent investigations of LukED indicate that the LukE and LukD proteins are highly conserved in $S$. aureus strains and have a sequence corresponding to the active $\operatorname{LukE}_{\mathrm{v}} \mathrm{D}_{\mathrm{v}}$ and not to the originally described sequence of LukED (Alonzo et al., 2012). In addition to neutrophils, the bicomponent toxins are active against monocytes and macrophages. Different species specificities have been observed for the different bi-component toxins. Human and rabbit neutrophils are PVLsensitive cells, while murine and Java monkey cells are, respectively, largely and fully resistant to PVL-mediated lysis (Loffler et al., 2010). It is therefore unlikely that the deleterious effects of PVL observed in the murine model of necrotizing pneumonia (see below) were caused by PVL-mediated neutrophils lysis (Labandeira-Rey et al., 2007; Zivkovic et al., 2011). In contrast, LukED is active against human, rabbit, and murine cells (Alonzo et al., 2012), while $\boldsymbol{\gamma}$-hemolysin activity has been mostly studied against human and murine cells.

The receptors for bi-component toxins are still largely uncharacterized. The murine TLR2 ectodomain has been described to bind LukS-PV, leading to inflammation (Zivkovic et al., 2011). In addition, LukF-PV has been described to bind murine TLR4 (Inden et al., 2009). However, these receptors are unlikely to be the high affinity receptors triggering very fast lysis at very low doses in human and rabbit granulocytes and primary monocytes. Indeed, the murine TLR2/TLR4-dependent effects were observed at concentrations a 100-fold greater than the ones triggering $100 \%$ lysis of human neutrophils, monocytes, and macrophages $(10 \mu \mathrm{g} / \mathrm{ml}$ vs. $100 \mathrm{ng} / \mathrm{ml}$; Gauduchon et al., 2001; Perret et al., in press). As previously described for $\alpha$-hemolysin, lipids have been described as receptors for LukS and LukF, although it is more likely that they act as co-receptors (Hakomori, 2003). LukS binds the ganglioside GM1, and LukF binds phosphatidylcholine (Noda et al., 1980). The latter interaction has been confirmed by crystallization of LukF-PV (Pedelacq et al., 1999), as well as with the homologous F component of $\gamma$-hemolysin, HlgB (Olson et al., 1999). Binding studies have shown that expression of the receptor for the S component of PVL and for HglC is limited to PVL-susceptible cells (Gauduchon et al., 2001). In contrast, the LukF-PV receptor is more broadly expressed (Meyer et al., 2009). Furthermore, $\mathrm{HlgB}$ seems to bind mainly to the corresponding S component on the host cell membrane (Meyer et al., 2009). These results indicate that the S components of PVL and $\gamma$-hemolysin drive the cell type susceptibilities. Interestingly, HlgC and LukS-PV share the same uncharacterized receptor on the surface of human granulocytes (Gauduchon et al., 2001). HlgC/HlgB and PVL thus probably target the same cell types. Furthermore, the two toxins are similarly potent at lysing granulocytes (Konig et al., 1997) and human macrophages (our unpublished results). Among recombinant bicomponent toxins, PVL and $\gamma$-hemolysin are extremely potent, while LukAB/GH and lukED are active at concentrations 100 -fold higher. The relative secretion of the different toxins in different conditions remains unknown, but this knowledge would help us to understand the physiological roles of the different leukotoxins.

\section{$\beta$-HEMOLYSIN}

The $P$. aeruginosa hemolytic phospholipase $\mathrm{C}$ ( $\mathrm{PlcHR})$, which is an extracellular sphingomyelinase, displays strong specificity for endothelial cells (Vasil et al., 2009). This targeting, which is mediated by a specific domain of the toxin and a saturable receptor, makes PlcHR cytotoxic to endothelial cells at concentrations 500-fold lower than the dosages toxic to epithelial cells or macrophages. Similarly, S. aureus $\beta$-hemolysin is selectively cytotoxic to monocytes and is inactive against lymphocytes, granulocytes, and fibroblasts (Walev et al., 1996). However, as monocytes are equally sensitive to sphingomyelinase $\mathrm{C}$ from $B$. cereus and from Streptomyces species, it is currently unknown if this result is due to a specific targeting of $\beta$-toxin to monocytes (possibly mediated by a specific receptor) or to a higher sensitivity of these cells to the toxin.

\section{PHENOL SOLUBLE MODULINS}

The current view concerning PSMs is that these peptides do not have a specific proteinaceous receptor required for cell lysis. Indeed, in contrast to other hemolysins, $\delta$-hemolysin is hemolytic to erythrocytes from numerous species and can lyse organelles, as well as bacterial protoplasts and spheroplasts (Kreger et al., 1971; Verdon et al., 2009). Due to its amphipathic $\alpha$-helix structure, $\delta$-hemolysin has a natural affinity for lipids. Binding is preferential in liquid-disordered domains compared to liquid-ordered raft domains. Lipid composition of eukaryotic and prokaryotic membranes may explain the activity spectrum of PSMs. PSMs show moderate lytic activity toward granulocytes, and this activity is observed for only a subset of PSMs and at high concentrations $(10 \mu \mathrm{g} / \mathrm{ml}$ for PSM $\alpha 3$ and $\delta$-hemolysin, $50 \mu \mathrm{g} / \mathrm{ml}$ for PSM-mec). In contrast, detection of those peptides by the innate immune system occurs at concentrations as low at $50 \mathrm{nM}$ (approximately $100 \mathrm{ng} / \mathrm{ml}$; Kretschmer et al., 2010), thus it is unclear if the prime function of PSMs is to lyse neutrophils or to activate them. PSMs show activity toward human erythrocytes at lower concentrations $(1 \mu \mathrm{g} / \mathrm{ml}$ or $0.1 \mu \mathrm{g} / \mathrm{ml}$ if co-incubated with $\beta$-hemolysin; Cheung et al., 2011).

\section{PREVALENCE AND GENE ORGANIZATION}

Both colonizing and clinical $S$. aureus isolates exhibit a large degree of heterogeneity. The observed heterogeneity can be due to (i) the presence or absence of a toxin gene, (ii) disruption of toxin-encoding loci, and (iii) variations in the expression level. Interestingly, some differences in the membrane-damaging toxin repertoire or in their level of expression have been linked to increased virulence or to antibiotic-resistance. The vast majority of $S$. aureus strains contain all the hemolysin genes, $h l a, h l b$, hld, and $h l g$. The prevalence of the $l u k E D$ genes is controversial. Indeed, one study found $l u k E D$ genes in $87 \%$ of $S$. aureus strains (Morinaga et al., 2003; Alonzo et al., 2012) while another group described a prevalence of about $30 \%$ in human clinical and colonizing isolates (Gravet et al., 1998, 1999, 2001). To the best of our knowledge, the prevalence of LukAB/GH has not been investigated in a large number of clinical strains, but these toxins are well-conserved in all sequenced strains (Shukla et al., 2010; Ventura et al., 2010). In contrast, the $l u k S-P V$ and $l u k F-P V$ genes are present in less than $5 \%$ of MSSA strains (Vandenesch et al., 2003; Shukla et al., 2010). 
LukS-PV and LukF-PV are encoded within lysogenic phages. A temperate phage $\phi S L T$ can convert $\mathrm{PVL}^{-}$strains into $\mathrm{PVL}^{+}$strains (Kaneko et al., 1997; Narita et al., 2001). Various lukS/lukF-PVtransducing phages have been described. This unique genetic organization makes PVL genes easily transmittable horizontally.

The $\beta$-hemolysin-encoding gene is a preferential locus for bacteriophage insertion. These insertions disrupt the $\beta$-hemolysin gene. Furthermore, most of the $\beta$-hemolysin-targeting bacteriophages simultaneously introduce genes encoding components of the immune evasion cluster (IEC), namely, the staphylokinase, the staphylococcal enterotoxins A and P, the staphylococcal complement inhibitor (SCIN), and the chemotaxis inhibitory protein of S. aureus (CHIPS; van Wamel et al., 2006). The vast majority $(89 \%)$ of human clinical isolates carry two to four components of the IEC and thus are $\beta$-hemolysin-negative (van Wamel et al., 2006). In contrast, most $S$. aureus isolated from bovine do not have the IEC and express $\beta$-hemolysin (Monecke et al., 2007).

Interestingly, two PSMs are encoded in specific virulence loci. Indeed, $\delta$-hemolysin is encoded within RNAIII, a highly structured $517 \mathrm{nt}$ RNA (Benito et al., 2000) that is part of the agr regulon (a master virulence regulator system). The PSM-mecencoding gene is found within the class A mec gene complex encoded on type II, III, and VIII SSCmec (Chatterjee et al., 2011), three methicillin-resistant cassettes integrated into the chromosome of certain MRSA strains. Importantly, this last finding provided a molecular link between the modulation of virulence and methicillin-resistance (Queck et al., 2009). However, the link between PSM-mec and increased virulence is controversial (Chatterjee et al., 2011; Kaito et al., 2011) and requires further investigation (see below). In addition, PSM $\alpha$ and $\alpha$-hemolysin are produced at higher level in CA-MRSA strains than in hospitalacquired (HA)-MRSA strains (Wang et al., 2007; Li et al., 2009), and PVL is present in most of the community-acquired (CA)MRSA lineages that have emerged worldwide (Vandenesch et al., 2003; Tristan et al., 2007). Although other factors, such as the arginine catabolic mobile element (ACME), have also been associated with CA-MRSA strains (Diep et al., 2006), the change in the repertoire or the quantity of membrane-damaging factors is also likely to participate in the high virulence of successful CA-MRSA clones.

\section{EPIDEMIOLOGY AND ROLE IN S. AUREUS-DISEASES}

The roles of $S$. aureus membrane-damaging factors have been investigated both by epidemiological studies in humans and by experimental infections with various mutants in diverse animal models.

\section{EPIDEMIOLOGY}

Robust epidemiological studies can only be performed on virulence factors that have a low prevalence and without association with a specific lineage. This requirement is true for PVL in CA-MSSA strains and for $\beta$-hemolysin regardless of methicillinresistance status. To the best of our knowledge (and based on Vandenesch and Lina, unpublished data), the presence of $\beta$-hemolysin has not been associated with any specific human diseases or with severity criteria. The low prevalence of this factor in human isolates suggests that this factor is less important in human infection than the presence of the IEC components. The high prevalence of $\alpha-$, $\gamma$-, and $\delta$-hemolysin and $\alpha$ and $\beta$-PSMs prevents epidemiological studies from assessing their roles in specific human diseases or association with severity criteria. Nevertheless, their high prevalence suggests that these factors play a key role in colonization and/or diseases. Although LukAB/GH is highly prevalent (Ventura et al., 2010), it has been reported to be absent in certain colonizing and clinical isolates (see Figure S5 in Dumont et al., 2011). It is thus unclear if epidemiological studies on LukAB/GH would be informative. An increased prevalence of lukED genes has been observed in clinical strains isolated from cases of impetigo (Gravet et al., 2001) and from patients presenting antibiotic-associated diarrhea (Gravet et al., 1999). Due to the limited and controversial knowledge regarding LukED prevalence, the biological significance of these interesting associations remains unclear. PSM-mec has been only recently identified, and epidemiological studies have yet to be performed (Chatterjee et al., 2011).

There is compelling evidence that PVL is associated with a severe form of CA-MSSA pneumonia occurring in otherwise healthy children and young adults (Lina et al., 1999; Gillet et al., 2002). PVL is also associated with increased severity, treatment duration, and extra osseous complications in bone and joint infections, especially in children (Bocchini et al., 2006; Dohin et al., 2007). The role of PVL in SSTI is more debated (Bae et al., 2009), but several studies demonstrate a significant association between PVL and CA-SSTI (Shallcross et al., 2010; Del Giudice et al., 2011). This association is particularly strong in primary skin lesions, such as furunculosis (Gravet et al., 2001; Del Giudice et al., 2009, 2011). In contrast, no clear role of PVL has been identified in CA-MRSA infections. However, epidemiological studies regarding PVL and CA-MRSA-diseases have proven difficult, due to the high prevalence of PVL in CA-MRSA strains in North America and to the clonality of these CA-MRSA strains (Bae et al., 2009). In a similar vein, PVL is statistically associated with major MRSA abscesses but does not seem to affect SSTI patients' outcome (Bae et al., 2009). Furthermore, PVL is not associated with hospital-acquired/ventilation associated MRSA pneumonia (Peyrani et al., 2011). Of note, in these two studies, $\mathrm{PVL}^{+}$strains are statistically associated with younger patients than $\mathrm{PVL}^{-}$strains. This observation suggests that PVL is a virulence factor in immunocompetent and not immunosenescent patients. Alternatively, an increase in the likelihood of being immunized against PVL with age might explain why $\mathrm{PVL}^{+}$strains are more often associated with infections in children and young adults than with infections in older patients. Indeed, serum antibody titers specific for $S$. aureus toxins increase with age (Hermos et al., 2010; Verkaik et al., 2010). However, Hermos and collaborators did not observe any protection against $\mathrm{PVL}^{+}$SSTI in patients with high anti-PVL antibody levels. In contrast, Rasigade et al. (2011) found that patients presenting a history of PVL-associated infections were protected from death in PVL-associated necrotizing pneumonia. Overall, these studies suggest that PVL-directed immunity does not protect the host from being re-infected and from developing severe infections, such as necrotizing pneumonia, but it may favor a positive outcome (survival) in severe diseases. 


\section{ANIMAL MODELS}

Numerous animal models have been used to study the impact of membrane-damaging factors on S. aureus infection (Table 2). Strikingly, while iron is known to be a limiting nutrient during infections, it is still unknown if hemolysis occurs in vivo and which hemolysin is important in acquiring iron. $\alpha$-Hemolysin is the key virulence factor emerging from in vivo studies. $\alpha$-Hemolysin is a critical virulence factor in brain abscesses (Kielian et al., 2001), SSTI (Kobayashi et al., 2011), and pneumonia (Bubeck Wardenburg et al., 2007). The role of $\alpha$-hemolysin in bacteremia is less obvious (Bayer et al., 1997), which is consistent with a major role of $\alpha$-hemolysin at epithelial surfaces (see below). In contrast, the role of the other hemolysins is still poorly defined. $\beta$-hemolysin promotes inflammation and lung injury in a mouse model of pneumonia (Hayashida et al., 2009), and $\gamma$-hemolysin promotes bacterial growth and triggers inflammation in a rabbit model of endophthalmitis (Supersac et al., 1998). LukAB/GH is important for survival in human blood and increases the bacterial burden in the kidney during a murine model of bloodstream infection (Dumont et al., 2011). Similarly, deletion of the $l u k E$ and $l u k D$ genes attenuates $S$. aureus virulence and decreases lethality in a murine model of bloodstream infection (Alonzo et al., 2012).

As described above and in contrast to several other $S$. aureus virulence factors, PVL is poorly cytotoxic to murine cells (Loffler

Table 2 | Membrane-damaging factors and their role in various diseases in various animal models.

\begin{tabular}{|c|c|c|c|c|c|}
\hline Disease & Animal & $\begin{array}{l}\text { Inoculum } \\
\text { (strain type) }\end{array}$ & $\begin{array}{l}\text { Virulence } \\
\text { factor }\end{array}$ & $\begin{array}{l}\text { Phenotype of the animal infected with the } \\
\text { mutant strain as compared to the WT strain }\end{array}$ & Reference \\
\hline Skin infection & Rabbit & $5 \times 10^{8}$ MRSA (USA 300 Lac) & $\begin{array}{l}\text { hla } \\
\text { PSM } \alpha \\
\text { PVL }\end{array}$ & $\begin{array}{l}\text { Decreased cfu, decreased abscess size } \\
\text { Decreased cfu, decreased abscess size } \\
\text { Decrease cfu, increased abscess size at } \\
\text { resolution stage }\end{array}$ & Kobayashi et al. (2011) \\
\hline Skin infection & Rabbit & $10^{8}$ MRSA (USA 300 Lac) & PVL & $\begin{array}{l}\text { Decreased lesion size, decreased necrotic } \\
\text { lesion size }\end{array}$ & Lipinska et al. (2011) \\
\hline Osteomyelitis & Rabbit & $4 \times 10^{8}$ MRSA (USA 300 Lac) & PVL & $\begin{array}{l}\text { No bone deformation at day } 7 \text {, decreased cfu at } \\
\text { day } 28\end{array}$ & Cremieux et al. (2009) \\
\hline $\begin{array}{l}\text { Necrotizing soft } \\
\text { tissue infection }\end{array}$ & Mice & $10^{9} \mathrm{cfu}$ & PVL & $\begin{array}{l}\text { No difference in cfu, No difference in skin lesion } \\
\text { size, decreased muscle lesions in BalB/c mice } \\
\text { not in C57BL6J mice }\end{array}$ & Tseng et al. (2009) \\
\hline $\begin{array}{l}\text { Necrotizing } \\
\text { pneumonia }\end{array}$ & Rabbit & $10^{10} \mathrm{cfu}$ (USA 300 SF8300) & PVL & Decreased mortality, decreased inflammation & Diep et al. (2010) \\
\hline $\begin{array}{l}\text { Necrotizing } \\
\text { pneumonia }\end{array}$ & Mice & $\begin{array}{l}\text { Purified PVL (3 } \mu g \\
\text { LukS }+3 \mu g \text { LukF) }\end{array}$ & PVL & Death, neutrophil recruitment & $\begin{array}{l}\text { Labandeira-Rey et al. } \\
\text { (2007) }\end{array}$ \\
\hline $\begin{array}{l}\text { Necrotizing } \\
\text { pneumonia }\end{array}$ & Mice & $2.10^{7} \mathrm{cfu}(\mathrm{LUG855)}$ & $P V L$ & Decreased mortality, decreased inflammation & \\
\hline Bacteremia & Rabbit & & PVL & $\begin{array}{l}\text { Decreased cfu in the kidney at } 24-48 \mathrm{~h} \mathrm{PI} \text { not at } \\
72 \mathrm{~h} \mathrm{PI}\end{array}$ & Diep et al. (2008) \\
\hline Bacteremia & Mice & $1.10^{6} \mathrm{cfu}$ (USA 300 Lac) & LukAB/GH & Decreased cfu in the kidney at day $4 \mathrm{PI}$ & Dumont et al. (2011) \\
\hline Bacteremia & Mice & $10^{8} \mathrm{cfu}(\mathrm{Mw} 2)$ & $\begin{array}{l}\text { PSM } \alpha \\
\text { PSM } \beta \\
\text { hld }\end{array}$ & $\begin{array}{l}\text { Decreased mortality, less TNF } \alpha \\
\text { No role } \\
\text { Decreased mortality, less TNF } \alpha\end{array}$ & Wang et al. (2007) \\
\hline Skin infection & Mice & $10^{7} \mathrm{cfu}(\mathrm{Mw} 2)$ & $\begin{array}{l}\text { PSM } \alpha \\
\text { PSM } \beta \\
\text { hld }\end{array}$ & $\begin{array}{l}\text { Decreased lesion size } \\
\text { Increased lesion size } \\
\text { No role }\end{array}$ & Wang et al. (2007) \\
\hline Bacteremia & Mice & $10^{8} \mathrm{cfu}(\mathrm{MSA} 890)^{1}$ & PSM-mec & Decreased mortality & Queck et al. (2009) \\
\hline Skin infection & Mice & $10^{7}$ cfu (MSA890) & PSM-mec & No dermonecrosis, no weight loss & \\
\hline Pneumonia & Mice & $2-4 \times 10^{8} \mathrm{cfu}(\mathrm{Lac})$ & hla & Decreased mortality & $\begin{array}{l}\text { Bubeck Wardenburg } \\
\text { et al. (2007) }\end{array}$ \\
\hline Pneumonia & Mice & $2-4 \times 10^{8} \mathrm{cfu}(\mathrm{MW} 2$ or Lac) & PVL & No effect & $\begin{array}{l}\text { Bubeck Wardenburg } \\
\text { et al. (2007) }\end{array}$ \\
\hline Pneumonia & Mice & $1.2 \times 10^{8} \mathrm{cfu}(8325.4)$ & hlb & Decreased inflammation, decreased lung injury & Hayashida et al. (2009) \\
\hline Pneumonia & Mice & $15 \mu \mathrm{g} \mathrm{hlb}$ & hlb & Increased inflammation, increased lung injury & Hayashida et al. (2009) \\
\hline Endophthalmitis & Rabbit & $10^{2} \mathrm{cfu}$ & hlg & $\begin{array}{l}\text { Decreased cfu at day } 4 \mathrm{Pl} \text {, decreased } \\
\text { inflammation at day } 3 \mathrm{PI}\end{array}$ & Supersac et al. (1998) \\
\hline Brain abscess & Mice & $10^{5} \mathrm{cfu}(\mathrm{RN} 6390)$ & hla & Decreased cfu, decreased inflammation & Kielian et al. (2001) \\
\hline
\end{tabular}

Due to controversial results, we present a larger coverage on studies testing the role of PVL. 'A strain with low production of core genome-encoded PSM. 
et al., 2010). The low activity of PVL against murine cells has cast doubt on the results showing an effect of PVL in murine models of pneumonia and SSTI (Bubeck Wardenburg et al., 2007, 2008; Labandeira-Rey et al., 2007; Brown et al., 2009; Tseng et al., 2009; Otto, 2010; Vandenesch et al., 2010). These phenotypes might be linked with the high inocula used in these studies, which might bypass the low sensitivity of murine cells. In some cases, rabbit infection models have also led to controversial results concerning the role of PVL. Indeed, depending on the studies, PVL has been shown to play either a major role in skin inflammation and lesions (Lipinska et al., 2011) or only a minor role in promoting bacterial replication and survival early on and even accelerating infection resolution and healing at later stages (Kobayashi et al., 2011). Similarly, PVL plays a minor role in S. aureus rabbit bacteremia (Diep et al., 2008), while it contributes to persistence and extra osseous involvement in rabbit osteomyelitis (Cremieux et al., 2009). Finally, experimental infections in rabbit have proven a good model for studying necrotizing pneumonia. In this model, PVL triggers massive lung inflammation, neutrophil recruitment, and promotes lung damage and death in infected animals. Importantly, this activity is dependent on the presence of vinblastine-susceptible cells, which include neutrophils and all other circulating leukocytes, supporting a role for PVL targeting of neutrophils in this immune pathology (Diep et al., 2010).

Phenol soluble modulins $\alpha$ have also been involved in promoting death in bacteremia models and increasing the extent of the skin lesions in experimental SSTI (Wang et al., 2007; Queck et al., 2009). Importantly, the role of PSM-mec has been studied in a strain expressing low levels of core genome-encoded PSMs, suggesting that the presence of PSM-mec might not provide a novel virulence attribute in the presence of highly expressed core genome-encoded PSM $\alpha$ (Queck et al., 2009; Chatterjee et al., 2011). Conversely, in another study, PSM-mec was shown to reduce the severity of $S$. aureus sepsis in a mouse systemic infection model, owing to its regulatory effect on core genome-encoded virulence factors (Kaito et al., 2011).

\section{INFLAMMATION AND DETECTION BY THE INNATE IMMUNE SYSTEM}

While it is clear that certain membrane-damaging toxins have evolved to specifically target innate immune cells, the converse is also true. Indeed, the innate immune system has evolved several pathways to sense membrane damage (Figure 1; Henry and Lemichez, 2012).

\section{PERTURBATION OF Ca ${ }^{2+}$ HOMEOSTASIS: NF-kB AND PLA2 ACTIVATION}

There is a large difference in $\mathrm{Ca}^{2+}$ concentration between the extracellular environment $\left(\left[\mathrm{Ca}^{2+}\right]>1 \mathrm{mM}\right)$ and the host cytoplasm $\left(\left[\mathrm{Ca}^{2+}\right]_{\mathrm{i}}<100 \mathrm{nM}\right)$. Pore formation leads to a rapid rise in intracellular calcium concentration associated with either direct influx through the pore or with a release from intracellular compartments, such as the endoplasmic reticulum. This calcium increase has been well exemplified in rabbit PMNs treated with sublytic $\alpha$-hemolysin doses (Suttorp and Habben, 1988). Depending on their frequency, oscillations in $\left[\mathrm{Ca}^{2+}\right]_{i}$ trigger activation of various transcription factors (Dolmetsch et al., 1998) including NF- $\mathrm{B}$. Calmodulin, a calcium binding protein, is the primary intracytoplasmic calcium sensor. Upon calcium binding-mediated conformation changes, calmodulin binds to and activates several proteins, including calcineurin, a protein phosphatase. Activated calcineurin activates the IKKb complex (I kappa B Kinase). Activated IKKb phosphorylates IKB (Frantz et al., 1994), a protein sequestering NF- $\kappa \mathrm{B}$ into the cytosol, leading to I $\kappa \mathrm{B}$ degradation, and the release of NF- $\kappa B$ (Henkel et al., 1993). One of the main NF- $\kappa \mathrm{B}$-inducible genes is IL-8 (CXCL8), a potent neutrophil chemoattractant. IL- 8 is produced by PMNs treated with sublytic doses of $\alpha$-hemolysin or PVL (Konig et al., 1994). This response is not limited to professional immune cells, as $\alpha$-hemolysin-treated alveolar epithelial cells also release IL-8 (Rose et al., 2002).

In addition to regulating NF- $\kappa$ B activation, increases in $\left[\mathrm{Ca}^{2+}\right]_{i}$ activate the cytoplasmic phospholipase A2 (PLA2). Cytoplasmic PLA2 hydrolyzes arachidonic acid-containing phospholipids, leading to the generation of arachidonic acid-derived lipid mediators, such as PGE2 and LTB4. An increase in $\left[\mathrm{Ca}^{2+}\right]_{\mathrm{i}}$ leads to relocation of cPLA2 to the phospholipid-containing plasma membrane and triggers its phosphorylation by a calmodulindependent kinase, leading to greater catalytic activity (reviewed in Hirabayashi et al., 2004). Treating human neutrophils or alveolar epithelial cells with sublytic doses of $\alpha$-hemolysin triggers LTB4 generation (Suttorp et al., 1987; Rose et al., 2002). In PMNs, LTB4 generation is abolished by chelation of extracellular calcium (Suttorp et al., 1987). Similarly, PVL triggers LTB4 secretion, although the influence of extracellular calcium has not been investigated (Hensler et al., 1994).

\section{PERTURBATION OF $\mathrm{K}^{+}$HOMEOSTASIS: MAPK AND INFLAMMASOME ACTIVATION}

While calcium concentration is higher in the extracellular environment than in the cytosol, the potassium $\left(\mathrm{K}^{+}\right)$gradient is inversely orientated. The intracellular potassium concentration $\left(\left[\mathrm{K}^{+}\right]_{\mathrm{i}}\right)$ is $143 \mathrm{mM}$, while the extracellular potassium concentration does not exceed $5 \mathrm{mM}$.

$\alpha$-Hemolysin triggers $\mathrm{K}^{+}$efflux upon insertion in the membrane of human keratinocytes. While the pore formed by $\alpha$ hemolysin at low concentrations is specific for monovalent cations (Walev et al., 1993), at higher doses, $\mathrm{Ca}^{2+}$ can also flow through the pore. Cells are capable of detecting a drop in $\left[\mathrm{K}^{+}\right]_{\mathrm{i}}$, which leads to the activation of several immune pathways. Indeed, MAPK p38 phosphorylation is observed following $\alpha$-hemolysin stimulation of a human keratinocyte cell line, and this phosphorylation is blocked by the presence of high extracellular $\left[\mathrm{K}^{+}\right]$(Kloft et al., 2009). Conversely, adding a $\mathrm{K}^{+}$ionophore, nigericin, to cells can recapitulate p38 activation in the absence of bacterial toxin, indicating that $\mathrm{K}^{+}$efflux is sufficient to activate p38 MAPK. In addition, osmotic stress triggered by sublethal $\alpha$-hemolysin doses activates p38 MAPK in epithelial cells (Ratner et al., 2006). p38 MAPK activation results in NF- $\kappa \mathrm{B}$ activation and IL-8 production.

In addition to activating the MAPK pathway, decreased $\left[\mathrm{K}^{+}\right]_{\mathrm{i}}$ is required to trigger another innate immune signaling pathway, namely, the inflammasome. The inflammasome is a cytosolic signaling platform assembled after sensing PAMPs or danger signals that leads to caspase- 1 activation (reviewed in Brodsky and Monack, 2009). Caspase- 1 is an inflammatory caspase that cleaves proIL- $1 \beta$ and proIL-18, leading to secretion of the corresponding 


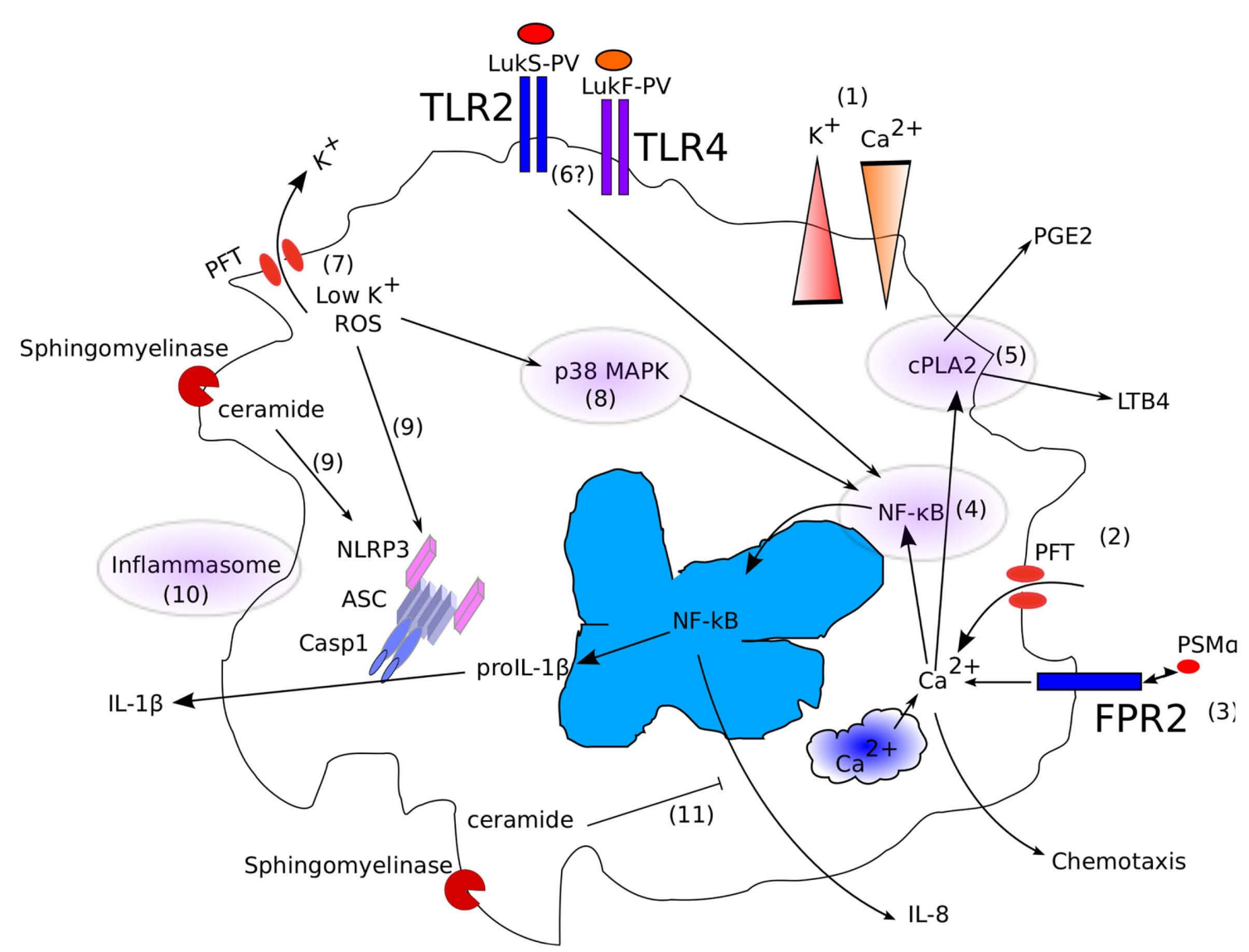

FIGURE 1 | Interplay between membrane-damaging (poly)peptides and the innate immune system. (1) In physiological conditions, differences in $\left[\mathrm{Ca}^{2+}\right]$ and $\left[\mathrm{K}^{+}\right]$are actively maintained between the extracellular space and the cytosol. (2) Insertion of a PFT or membrane damage leads to a direct or indirect rise in $\left[\mathrm{Ca}^{2+}\right]_{i}$. (3) Similarly, engagement of FPR2 by PSM $\alpha$ triggers an increase in $\left[\mathrm{Ca}^{2+}\right]_{i}$. (4) $\left[\mathrm{Ca}^{2+}\right]_{i}$ controls NF-kB and (5) cPLA2 activation. (6) TLR2 and 4 might also trigger NF-kB translocation in the nucleus by sensing LukS-PV and LukF-PV. (7) Insertion of a PFT or membrane damage leads to a rapid fall in $\left[\mathrm{K}^{+}\right]_{i}$, leading to (8) MAP kinase and (9) NLRP3 inflammasome activation. (10) Ceramide generated by $\beta$-hemolysin might also directly activate the NLRP3 inflammasome. (11) In addition, ceramide has been reported to inhibit IL-8 secretion. mature cytokines. Furthermore, caspase-1 triggers a form of programmed necrosis known as pyroptosis (Cookson and Brennan, 2001). Inflammasome-dependent IL- $1 \beta$ release is critical for neutrophil recruitment and bacterial clearance in a mouse model of $S$. aureus cutaneous infection (Miller et al., 2007). Numerous PFTs, including $\alpha$-hemolysin and $\beta$-hemolysin on human monocytes (Bhakdi et al., 1989; Walev et al., 1996; Craven et al., 2009), PVL on human macrophages (Perret et al., in press), and $\alpha$ - and $\gamma$ hemolysins on murine microglial cells (Hanamsagar et al., 2011) activate IL- $1 \beta$ release. PFT activates the inflammasome via the inflammasome receptor NLRP3, which is also known as cryopyrin, and the adaptor protein ASC. It is still unclear how pore formation is translated into a NLRP3 signal (reviewed in Martinon, 2010). Intracellular $\mathrm{K}^{+}$depletion seems to be a key event controlling this activation. Indeed, $\alpha$-hemolysin-mediated activation of the NLRP3 inflammasome can be inhibited in presence of high extracellular $\mathrm{K}^{+}$concentrations (Fernandes-alnmeri et al., 2007). Furthermore, as described before for MAP kinase activation, treatment of macrophages with nigericin, a bacterial $\mathrm{K}^{+}$ ionophore, triggers NLRP3-mediated inflammasome activation
(Mariathasan et al., 2006). Other possible mechanisms include toxin-mediated destabilization of lysosomes with the concomitant release of cathepsins into the host cytosol (Hornung et al., 2008) or sensing of ceramide by NLRP3, which might be relevant following $\beta$-hemolysin intoxication (Vandanmagsar et al., 2011).

\section{FPR2 AND THE DETECTION OF PSMs}

While the two immune responses described above are linked to membrane-damaging activity, PSMs can trigger intracellular $\mathrm{Ca}^{2+}$ flux, chemotaxis, and IL-8 secretion independently of membranedamaging. Indeed, a host receptor, the formyl peptide receptor 2 (FPR2/ALX), can detect PSMs at nanomolar concentrations (Kretschmer et al., 2010). Despite its name, FPR2 detects nonformylated PSMs as efficiently as formylated PSMs. To date, it is not yet understood whether the innate immune system has evolved FPR2-mediated sensing of PSMs to detect Staphylococcus species or whether highly virulent $S$. aureus strains have evolved PSMs targeting of FPR2 to trigger a massive recruitment of neutrophils associated with massive leukotoxic activity (Kretschmer et al., 2010; Rautenberg et al., 2011). 


\section{TLR2, TLR4, AND PVL DETECTION}

In necrotizing pneumonia, PVL is associated with massive inflammation leading to necrotic lesions in human lung necropsies (Gillet et al., 2002) and in animal models (Labandeira-Rey et al., 2007; Diep et al., 2010). While consensus view is that this inflammation is due to the inflammatory necrotic death of neutrophils and the release of associated DAMPs (Krysko et al., 2011), two studies have demonstrated the binding of LukS-PV and LukF-PV by TLR2 (Zivkovic et al., 2011) and TLR4 (Inden et al., 2009), respectively. While contamination with LPS, lipopeptides, or cellwall component is always difficult to exclude, these studies suggest that PFT might be a novel PAMP recognized by TLRs.

\section{NON-LYTIC FUNCTIONS OF THE MEMBRANE-DAMAGING POLYPEPTIDES}

To date, most of these factors have been characterized for their hemolytic properties and their ability to lyse host cells. However, membrane-damaging activity might only be the tip of the iceberg, hiding more physiological functions. In this section, we review alternative functions recently uncovered for these virulent factors (Figure 2).

\section{RECEPTOR ACTIVATION}

As described above, the host receptors targeted by these different toxins remain unknown in most cases. However, ADAM10 has been recently identified as a $\alpha$-hemolysin receptor (Wilke and Bubeck Wardenburg, 2010). Importantly, $\alpha$-hemolysin binding to ADAM10 increases its metalloprotease activity and targets it to caveolae. Localized ADAM10 activation results in E-cadherin cleavage and disruption of intercellular tight junctions leading to epithelial barrier disruption (Tunggal et al., 2005). Surprisingly, the ability of $\alpha$-hemolysin to form a pore is critical for ADAM10 activation, but it can be achieved at sublytic concentrations of $\alpha$ hemolysin, suggesting that ion flux through $\alpha$-hemolysin pores might be important for activating ADAM10 (Inoshima et al., 2011).

\section{ESCAPE FROM THE PHAGOSOME}

Staphylococcus aureus is classically considered to be an extracellular pathogen. However, clear evidence indicates that in the host, S. aureus can survive within an intracellular compartment (Bayles et al., 1998; Gresham et al., 2000; Giese et al., 2011), which may be relevant during persistent infections (Clement et al., 2005; Plouin-Gaudon et al., 2006). Importantly, S. aureus is found intracellularly in non-professional phagocytes, either in a membranebound compartment or in the host cytosol. Escape into the host cytosol involves a synergistic activity of $\delta$-toxin or PSM $\beta$ and $\beta$ toxin (Giese et al., 2011). Furthermore, $\alpha$-hemolysin is involved in phagosomal membrane lysis in CFTR-deficient cells, possibly explaining the persistence of $S$. aureus in cystic fibrosis patients (Jarry and Cheung, 2006; Jarry et al., 2008; Giese et al., 2009).

\section{ADHESION}

Panton Valentine leukocidin positive strains display stronger attachment to the cellular basement membrane than $\mathrm{PVL}^{-}$strains (De Bentzmann et al., 2004). Surprisingly, this function was ascribed to the ability of LukS-PV signal peptides (SPs) to interact with heparan sulfates in the extracellular matrix (Tristan et al.,
2009). While the interaction between LukS-PV SPs and heparan sulfate is of relatively low affinity, the large number of LukS-PV SPs associated with the cell-wall together with the large number of heparan sulfate ligands present could compensate for the low affinity by a high-avidity binding. The relevance of this binding to PVL-mediated pathogenesis remains to be addressed.

\section{INTERFERENCE WITH INFLAMMATORY PATHWAYS}

While $\beta$-hemolysin has mainly been characterized for its hemolytic activity, it differs from the other membrane-damaging (poly)peptides described above in its unique neutral sphingomyelinase activity. Sphingomyelin hydrolysis in eukaryotic membranes leads to the release of a very potent second messenger, ceramide, as well as to the release of the chemotactic molecule sphingosine-1-phosphate. $\beta$-hemolysin inhibits IL-8 production by endothelial cells in a manner similar to that of exogenous ceramide. This inhibition of IL-8 production correlates with a decrease in neutrophil transmigration across the endothelial barrier (Tajima et al., 2009), suggesting that $\beta$-hemolysin could cooperate with other S. aureus chemotaxis inhibitors, such as CHIPS (Foster, 2005).

\section{BIOFILM REGULATION}

Phenol soluble modulins- $\beta$ in S. epidermidis have been convincingly demonstrated to participate in the maturation of the biofilm structure, specifically in formation of the intra-biofilm channels, and in mediating bacterial detachment from the biofilm at high concentrations. In a mouse model of catheter-related infection, PSM $\beta$ were essential in disseminating from the catheter biofilm to systemic organs (Wang et al., 2011). PSM $\beta$ in S. aureus share the $\alpha$-helical amphipathic structure of S. epidermidis PSM $\beta$. PSM $\beta$ are thus likely to perform the same biofilm regulatory functions in $S$. aureus. Similarly, $\beta$-toxin, in addition to its neutral sphingomyelinase activity, has a structure reminiscent of the DNAse I protein. In presence of exogenous DNA, $\beta$-toxin displays the unique ability to oligomerize covalently and precipitate DNA. $\beta$-hemolysin mutants have a reduced adherence and are defective in biofilm formation, suggesting that this oligomerization activity in presence of DNA could participate in biofilm formation, possibly by forming a nucleoprotein network facilitating biofilm structuration (Huseby et al., 2010).

\section{GLOBAL DYSREGULATION}

As mentioned above, PSM-mec was the first virulence factor identified in the SCCmec element, which carries the methicillinresistance genes (Queck et al., 2009). Beside its direct cytolytic and pro-inflammatory functions, the PSM-mec peptide and its messenger RNA were found to suppress colony spreading and to enhance biofilm formation, while the PSM-mec mRNA also repressed the synthesis of the core genome-encoded PSM $\alpha$ (Kaito et al., 2011). However, as this latter effect seems to be observed only upon ectopic expression of PSM-mec from a plasmid, its relevance is questionable (Chatterjee et al., 2011). The mechanism for this dysregulation is still unknown but is reminiscent of the regulatory effect observed with the toxic-shock syndrome toxin-1 (TSST-1), which represses the transcription of many exoprotein genes (Vojtov et al., 2002). Similarly, PVL promotes the 
(1) a-hly-mediated epithelial barrier disruption

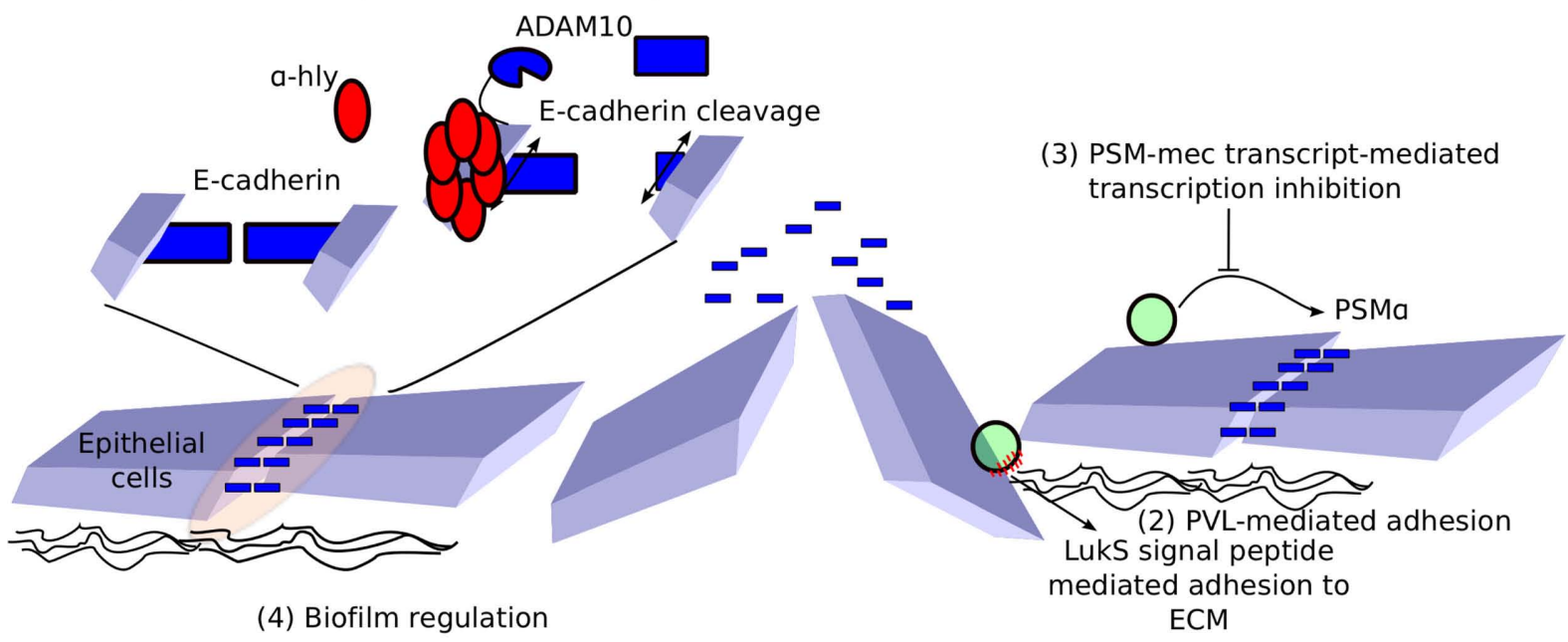

(5) antibacterial activity

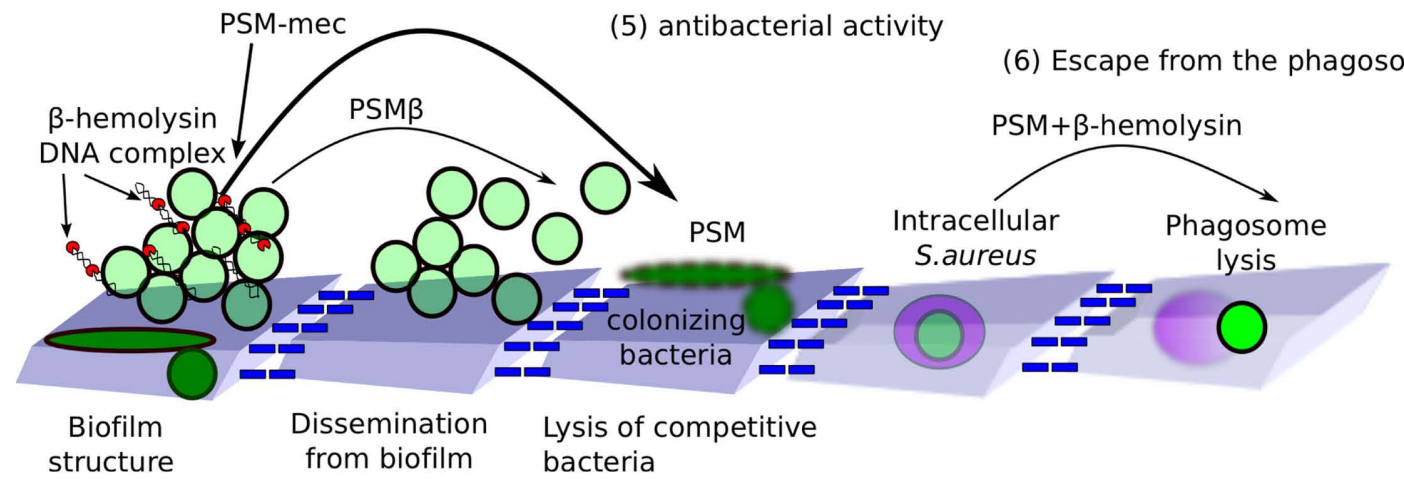

FIGURE 2 | Non-lytic functions of hemolysins, bi-component toxins, and PSMs. (1) E-cadherin is important for maintaining tight junctions and epithelial barrier function. $\alpha$-Hemolysin binds ADAM10 and relocalizes it to

E-cadherin-containing microdomains. ADAM10 cleaves E-cadherin, leading to loss in epithelial barrier function. (2) Exposure of the underlying glycosaminoglycans-rich extracellular matrix to LukS-PV signal peptide favors S. aureus adhesion. (3) PSM-mec RNA controls the transcription of virulence factors, including PSM $\alpha$. (4) $\beta$-Hemolysin binds DNA, forming nucleoproteins nucleating $S$. aureus biofilm. PSM $\beta$ acts as surfactant, promoting the formation of intra-biofilm tunnels and bacterial dissemination from biofilms. PSM-mec enhances biofilm formation (5) In addition, PSMs have antibacterial activity, which may be relevant in lysing competing colonizing bacteria. (6) Finally, PSMs in synergy with $\beta$-hemolysin participate in phagosome lysis and escape into the host cytosol. expression of staphylococcal protein A at the transcriptional level, which is an effect that could synergize with the pro-inflammatory activity of PVL and contribute to the pathogenesis of necrotizing pneumonia (Labandeira-Rey et al., 2007). Unexpectedly, this dysregulatory effect is restricted to the 8325-4 lineage (Vandenesch, unpublished), limiting the clinical relevance of this observation.

\section{ANTIBACTERIAL ACTIVITY}

$\delta$-Toxin lyses bacterial protoplasts and spheroblasts. Similarly, the PSM $\beta$-like peptides SLUSH-A, B, and C have been isolated from S. lugdunensis (Donvito et al., 1997; Rautenberg et al., 2011) and are described as having discrete anti-staphylococcal activity. PSM $\alpha$ and, to a lesser extent, PSM $\beta$ demonstrate bacteriostatic activity against Legionella at concentration 10-fold lower than the concentrations required to lyse $10 \%$ of a human erythrocytes suspension (Marchand et al., 2011). Finally, the antimicrobial activity against S. pyogenes and M. luteus present in the supernatant of CA-MRSA is abolished in mutants with the PSM $\alpha$ and $\beta$ genes deleted. Furthermore, PSM $\alpha 1$ and PSM $\alpha 2$, when deleted from their two Nter aminoacids, display a high bacteriolytic activity against S. pyogenes (Joo et al., 2011). The processing mechanisms responsible for generating these potent antimicrobial peptides from inactive PSMs is still unknown but might be a key regulatory step, allowing a switch of target from host cells to competing bacteria. Overall, these studies suggest that PSMs, possibly in conjunction with host antimicrobial peptides (Cogen et al., 2010), help S. aureus to compete with other bacteria colonizing the same ecological niche. As CA-MRSA are robust PSM producers, this colonization advantage could explain its rapid spread worldwide (Joo et al., 2011). The relevance of this antibacterial activity in colonization and infection remains to be investigated.

\section{CONCLUSION AND PERSPECTIVES}

While the hemolytic and leukotoxic activities of $S$. aureus have been known for more than a century, the molecular nature of the factors involved in this bacterium's pathogenesis are still being uncovered. The identification of $\alpha$-hemolysin receptors has highlighted the key role of this virulence factors in several $S$. 
aureus-diseases involving epithelial barrier disruption. Similarly, identifying the host receptors for the other membrane-damaging toxins is likely to yield novel insights into the physiological and specific functions of the different factors and to help us progress beyond the apparent redundancy of all these factors. Furthermore, the putative role of hemolysins, leukotoxins, and PSMs in $S$. aureus colonization is still uncharacterized but should provide important knowledge on the balance between commensalism and infection.

While hemolysis and leukotoxicity have stood as the major role of these virulence factors for decades, it is increasingly clear that the membrane-damaging toxins and peptides might have other functions besides killing host cells. These other functions are now wellestablished for $\alpha$-hemolysin, but secondary functions for other $S$. aureus secreted virulence factors are also emerging as a paradigm, as illustrated in this review. In most instances, the relevance of these functions as compared to their membrane-damaging functions remains to be established.

Another key challenge in the field will be to understand the temporal and spatial regulation of these different virulence factors. Indeed, different in vitro growth conditions are used to obtain secretion of the different membrane-damaging factors, suggesting that these virulence factors are secreted in response to different environmental cues or at different stages during colonization or infection. Furthermore, differential diffusion of the toxins and peptides within tissues might lead to different functions

\section{REFERENCES}

Alonzo Iii, F., Benson, M. A., Chen, J., Novick, R. P., Shopsin, B., and Torres, V. J. (2012). Staphylococcus aureus leukocidin ED contributes to systemic infection by targeting neutrophils and promoting bacterial growth in vivo. Mol. Microbiol. 83, 423-435.

Bae, I. G., Tonthat, G. T., Stryjewski, M. E., Rude, T. H., Reilly, L. F., Barriere, S. L., Genter, F. C., Corey, G. R., and Fowler, V. G. Jr. (2009). Presence of genes encoding the pantonvalentine leukocidin exotoxin is not the primary determinant of outcome in patients with complicated skin and skin structure infections due to methicillin-resistant Staphylococcus aureus: results of a multinational trial. J. Clin. Microbiol. 47, 3952-3957.

Bantel, H., Sinha, B., Domschke, W., Peters, G., Schulze-Osthoff, K., and Janicke, R. U. (2001). alpha-Toxin is a mediator of Staphylococcus aureusinduced cell death and activates caspases via the intrinsic death pathway independently of death receptor signaling. J. Cell Biol. 155, 637-648.

Bayer, A. S., Ramos, M. D., Menzies, B. E., Yeaman, M. R., Shen, A. J., and Cheung, A. L. (1997). Hyperproduction of alpha-toxin by Staphylococcus aureus results in paradoxically reduced virulence in experimental

(e.g., sublytic vs. lytic concentrations) at various distances from the bacteria (e.g., local vs. systemic effects).

As noted in this review, these virulence factors interact intimately with the immune system by both actively targeting immune cells and being actively detected by the innate immune system. To date, most of the research has focused on neutrophils, but endothelial cells and epithelial cells are also emerging as central players in triggering and regulating the immune responses (Dolowschiak et al., 2010; Teijaro et al., 2011). Furthermore, dendritic cells and inflammatory monocytes are key in regulating inflammatory responses at the epithelial barrier. Study of the interaction between these virulence factors and host cells in more physiological models is thus likely to provide us novel important findings.

The spread of highly virulent CA-MRSA is a major concern. Increased prevalence of leukotoxins, such as PVL, and increased expression of membrane-damaging factors, such as $\alpha$-hemolysin and PSMs, have been observed in these strains. A better understanding of the synergistic actions of these virulence factors in relevant animal models is required to understand their potential roles in the worldwide spread of these bacteria.

\section{ACKNOWLEDGMENTS}

We thank Magali Perret for critically reading this manuscript. Thomas Henry laboratory is supported by a FINOVI young investigator grant (http://www.finovi.org/en:start) and a Marie Curie Reintegration Grant (\#PIRG07-GA-2010-268399).

in children. Pediatrics 117, 433-440. Brodsky, I. E., and Monack, D. (2009) NLR-mediated control of inflammasome assembly in the host response against bacterial pathogens. Semin. Immunol. 21, 199-207.

Brown, E. L., Dumitrescu, O., Thomas, D., Badiou, C., Koers, E. M., Choudhury, P., Vazquez, V., Etienne, J., Lina, G., Vandenesch, F., and Bowden, M. G. (2009). The PantonValentine leukocidin vaccine protects mice against lung and skin infections caused by Staphylococcus aureus USA300. Clin. Microbiol. Infect. 15, 156-164.

Bubeck Wardenburg, J., Bae, T., Otto, M., Deleo, F. R., and Schneewind, O. (2007). Poring over pores: alphahemolysin and Panton-Valentine leukocidin in Staphylococcus aureus pneumonia. Nat. Med. 13 1405-1406.

Bubeck Wardenburg, J., PalazzoloBallance, A. M., Otto, M., Schneewind, O., and Deleo, F. R. (2008). Panton-Valentine leukocidin is not a virulence determinant in murine models of communityassociated methicillin-resistant Staphylococcus aureus disease. J. Infect. Dis. 198, 1166-1170.

Chatterjee, S. S., Chen, L., Joo, H. S., Cheung, G. Y., Kreiswirth, B. N., and Otto, M. (2011). Distribution and regulation of the mobile genetic element-encoded phenol-soluble modulin PSM-mec in methicillin-resistant Staphylococcus aureus. PLoS ONE 6, e28781. doi:10.1371/journal.pone.0028781

Cheung, G. Y., Duong, A. C., and Otto, M. (2011). Direct and synergistic hemolysis caused by Staphylococcus phenol-soluble modulins: implications for diagnosis and pathogenesis. Microbes Infect. doi: 10.1016.j.micinf.2011.11.013. [Epub ahead of print].

Clement, S., Vaudaux, P., Francois, P., Schrenzel, J., Huggler, E., Kampf, S., Chaponnier, C., Lew, D., and Lacroix, J. S. (2005). Evidence of an intracellular reservoir in the nasal mucosa of patients with recurrent Staphylococcus aureus rhinosinusitis. J. Infect. Dis. 192, 1023-1028.

Cogen, A. L., Yamasaki, K., Sanchez, K. M., Dorschner, R. A., Lai, Y., Macleod, D. T., Torpey, J. W., Otto, M., Nizet, V., Kim, J. E., and Gallo, R. L. (2010). Selective antimicrobial action is provided by phenol-soluble modulins derived from Staphylococcus epidermidis, a normal resident of the skin. J. Invest. Dermatol. 130, 192-200.

Cookson, B. T., and Brennan, M. A. (2001). Pro-inflammatory programmed cell death. Trends Microbiol. 9, 113-114. 
Craven, R. R., Gao, X., Allen, I. C., Gris, D., Bubeck Wardenburg, J., Mcelvania-Tekippe, E., Ting, J. P., and Duncan, J. A. (2009). Staphylococcus aureus alpha-hemolysin activates the NLRP3-inflammasome in human and mouse monocytic cells. PLoS ONE 4, e7446. doi:10.1371/journal.pone.0007446

Cremieux, A. C., Dumitrescu, O., Lina, G., Vallee, C., Cote, J. F., Muffat-Joly, M., Lilin, T., Etienne, J., Vandenesch, F., and Saleh-Mghir, A. (2009). Pantonvalentine leukocidin enhances the severity of communityassociated methicillin-resistant Staphylococcus aureus rabbit osteomyelitis. PLoS ONE 4, e7204. doi:10.1371/journal.pone.0007204

De Bentzmann, S., Tristan, A., Etienne, J., Brousse, N., Vandenesch, F., and Lina, G. (2004). Staphylococcus aureus isolates associated with necrotizing pneumonia bind to basement membrane type I and IV collagens and laminin. J. Infect. Dis. 190, 1506-1515.

Del Giudice, P., Bes, M., Hubiche, T., Blanc, V., Roudiere, L., Lina, G., Vandenesch, F., and Etienne, J. (2011). Panton-Valentine leukocidinpositive Staphylococcus aureus strains are associated with follicular skin infections. Dermatology (Basel) 222, 167-170.

Del Giudice, P., Blanc, V., De Rougemont, A., Bes, M., Lina, G., Hubiche, T., Roudiere, L., Vandenesch, F., and Etienne, J. (2009). Primary skin abscesses are mainly caused by Panton-Valentine leukocidinpositive Staphylococcus aureus strains. Dermatology (Basel) 219, 299-302.

Diep, B. A., Chan, L., Tattevin, P., Kajikawa, O., Martin, T. R., Basuino, L., Mai, T. T., Marbach, H., Braughton, K. R., Whitney, A. R., Gardner, D. J., Fan, X., Tseng, C. W., Liu, G. Y., Badiou, C., Etienne, J., Lina, G., Matthay, M. A., Deleo, F. R., and Chambers, H. F. (2010). Polymorphonuclear leukocytes mediate Staphylococcus aureus PantonValentine leukocidin-induced lung inflammation and injury. Proc. Natl. Acad. Sci. U.S.A. 107, 5587-5592.

Diep, B. A., Gill, S. R., Chang, R. F., Phan, T. H., Chen, J. H., Davidson, M. G., Lin, F., Lin, J., Carleton, H. A., Mongodin, E. F., Sensabaugh, G. F., and Perdreau-Remington, F. (2006). Complete genome sequence of USA300, an epidemic clone of community-acquired meticillinresistant Staphylococcus aureus. Lancet 367, 731-739.
Diep, B. A., Palazzolo-Ballance, A. M., Tattevin, P., Basuino, L., Braughton, K. R., Whitney, A. R., Chen, L., Kreiswirth, B. N., Otto, M., Deleo, F. R., and Chambers, H. F. (2008). Contribution of Panton-Valentine leukocidin in community-associated methicillinresistant Staphylococcus aureus pathogenesis. PLoS ONE 3, e3198. doi:10.1371/journal.pone.0003198

Doery, H. M., Magnusson, B. J., Cheyne, I. M., and Sulasekharam, J. (1963). A phospholipase in staphylococcal toxin which hydrolyses sphingomyelin. Nature 198, 1091-1092.

Dohin, B., Gillet, Y., Kohler, R., Lina, G., Vandenesch, F., Vanhems, P., Floret, D., and Etienne, J. (2007). Pediatric bone and joint infections caused by Panton-Valentine leukocidin-positive Staphylococcus aureus. Pediatr. Infect. Dis. J. 26, 1042-1048.

Dolmetsch, R. E., Xu, K., and Lewis, R. S. (1998). Calcium oscillations increase the efficiency and specificity of gene expression. Nature 392, 933-936.

Dolowschiak, T., Chassin, C., Ben Mkaddem, S., Fuchs, T. M., Weiss, S., Vandewalle, A., and Hornef, M. W. (2010). Potentiation of epithelial innate host responses by intercellular communication. PLoS Pathog. 6, e1001194. doi:10.1371/journal.ppat.1001194

Donvito, B., Etienne, J., Denoroy, L., Greenland, T., Benito, Y., and Vandenesch, F. (1997). Synergistic hemolytic activity of Staphylococcus lugdunensis is mediated by three peptides encoded by a nonagr genetic locus. Infect. Immun. 65, 95-100.

Dumont, A. L., Nygaard, T. K., Watkins, R. L., Smith, A., Kozhaya, L., Kreiswirth, B. N., Shopsin, B., Unutmaz, D., Voyich, J. M., and Torres, V. J. (2011). Characterization of a new cytotoxin that contributes to Staphylococcus aureus pathogenesis. Mol. Microbiol. 79, 814-825.

Fernandes-Alnemri, T., Wu, J., Yu, J. W., Datta, P., Miller, B., Jankowski, W., Rosenberg, S., Zhang, J., and Alnemri, E. S. (2007). The pyroptosome: a supramolecular assembly of ASC dimers mediating inflammatory cell death via caspase-1 activation. Cell Death Differ. 14, 1590-1604.

Foster, T. J. (2005). Immune evasion by staphylococci. Nat. Rev. Microbiol.3, 948-958.

Frantz, B., Nordby, E., Bren, G., Steffan, N., Paya, C., Kincaid, R., Tocci, M., O'Keefe, S., and O'Neill, E. (1994).
Calcineurin acts in synergy with PMA to inactivate I kappa B/MAD3, an inhibitor of NF-kappa B. EMBO J. 13, 861-870.

Galdiero, S., and Gouaux, E. (2004). High resolution crystallographic studies of alpha-hemolysinphospholipid complexes define heptamer-lipid head group interactions: implication for understanding protein-lipid interactions. Protein Sci. 13, 1503-1511.

Gauduchon, V., Werner, S., Prevost, G. Monteil, H., and Colin, D. A. (2001) Flow cytometric determination of Panton-Valentine leucocidin S component binding. Infect. Immun. 69, 2390-2395.

Giese, B., Dittmann, S., Paprotka, K., Levin, K., Weltrowski, A., Biehler, D., Lam, T. T., Sinha, B., and Fraunholz, M. J. (2009). Staphylococcal alpha-toxin is not sufficient to mediate escape from phagolysosomes in upper-airway epithelial cells. Infect. Immun. 77, 3611-3625.

Giese, B., Glowinski, F., Paprotka, K., Dittmann, S., Steiner, T., Sinha, B., and Fraunholz, M. J. (2011). Expression of delta-toxin by Staphylococcus aureus mediates escape from phago-endosomes of human epithelial and endothelial cells in the presence of beta-toxin. Cell. Microbiol. 13, 316-329.

Gillet, Y., Issartel, B., Vanhems, P., Fournet, J. C., Lina, G., Bes, M., Vandenesch, F., Piemont, Y., Brousse, N., Floret, D., and Etienne, J. (2002). Association between Staphylococcus aureus strains carrying gene for Panton-Valentine leukocidin and highly lethal necrotising pneumonia in young immunocompetent patients. Lancet 359, 753-759.

Gravet, A., Colin, D. A., Keller, D. Girardot, R., Monteil, H., and Prevost, G. (1998). Characterization of a novel structural member, LukELukD, of the bi-component staphylococcal leucotoxins family. FEBS Lett. 436, 202-208.

Gravet, A., Couppie, P., Meunier, O. Clyti, E., Moreau, B., Pradinaud, R., Monteil, H., and Prevost, G. (2001). Staphylococcus aureus isolated in cases of impetigo produces both epidermolysin $\mathrm{A}$ or $\mathrm{B}$ and LukE-LukD in $78 \%$ of 131 retrospective and prospective cases. J. Clin. Microbiol. 39, 4349-4356.

Gravet, A., Rondeau, M., Harf-Monteil, C., Grunenberger, F., Monteil, H., Scheftel, J. M., and Prevost, G. (1999). Predominant Staphylococcus aureus isolated from antibioticassociated diarrhea is clinically relevant and produces enterotoxin $\mathrm{A}$ and the bicomponent toxin LukE-lukD. J. Clin. Microbiol. 37, 4012-4019.

Gresham, H. D., Lowrance, J. H., Caver, T. E., Wilson, B. S., Cheung, A. L., and Lindberg, F. P. (2000). Survival of Staphylococcus aureus inside neutrophils contributes to infection. J. Immunol. 164, 3713-3722.

Guillet, V., Roblin, P., Werner, S., Coraiola, M., Menestrina, G., Monteil, H., Prevost, G., and Mourey, L. (2004). Crystal structure of leucotoxin S component: new insight into the Staphylococcal beta-barrel poreforming toxins. J. Biol. Chem. 279, 41028-41037.

Hakomori, S. (2003). Structure, organization, and function of glycosphingolipids in membrane. Curr. Opin. Hematol. 10, 16-24.

Hanamsagar, R., Torres, V., and Kielian, T. (2011). Inflammasome activation and IL-1beta/IL-18 processing are influenced by distinct pathways in microglia. J. Neurochem. 119, 736-748.

Hayashida, A., Bartlett, A. H., Foster, T. J., and Park, P. W. (2009). Staphylococcus aureus beta-toxin induces lung injury through syndecan-1. Am. J. Pathol. 174, 509-518.

Henkel, T., Machleidt, T., Alkalay, I., Kronke, M., Ben-Neriah, Y., and Baeuerle, P. (1993). Rapid proteolysis of I kappa B-alpha is necessary for activation of transcription factor NF-kappa B. Nature 365, 182-185.

Henry, T., and Lemichez, E. (2012). "Host cell responses to bacterial toxins," in Host-Pathogen Interactions: At the Frontier of the Cellular Microbiology, ed. E. Ghigo.

Hensler, T., Konig, B., Prevost, G., Piemont, Y., Koller, M., and Konig W. (1994). Leukotriene B4 generation and DNA fragmentation induced by leukocidin from Staphylococcus aureus: protective role of granulocyte-macrophage colonystimulating factor (GM-CSF) and GCSF for human neutrophils. Infect. Immun. 62, 2529-2535.

Hermos, C. R., Yoong, P., and Pier, G. B. (2010). High levels of antibody to panton-valentine leukocidin are not associated with resistance to Staphylococcus aureus-associated skin and soft-tissue infection. Clin. Infect. Dis. 51, 1138-1146.

Hirabayashi, T., Murayama, T., and Shimizu, T. (2004). Regulatory mechanism and physiological role of cytosolic phospholipase A2. Biol. Pharm. Bull. 27, 1168-1173. 
Hornung, V., Bauernfeind, F., Halle, A., Samstad, E. O., Kono, H., Rock, K. L., Fitzgerald, K. A., and Latz, E. (2008). Silica crystals and aluminum salts activate the NALP3 inflammasome through phagosomal destabilization. Nat. Immunol. 9, 847-856.

Huseby, M., Shi, K., Brown, C. K., Digre, J., Mengistu, F., Seo, K. S., Bohach, G. A., Schlievert, P. M., Ohlendorf, D. H., and Earhart, C. A. (2007). Structure and biological activities of beta toxin from Staphylococcus aureus. J. Bacteriol. 189, 8719-8726.

Huseby, M. J., Kruse, A. C., Digre, J., Kohler, P. L., Vocke, J. A., Mann, E. E., Bayles, K. W., Bohach, G. A., Schlievert, P. M., Ohlendorf, D. H., and Earhart, C. A. (2010). Beta toxin catalyzes formation of nucleoprotein matrix in staphylococcal biofilms. Proc. Natl. Acad. Sci. U.S.A. 107, 14407-14412.

Inden, K., Kaneko, J., Miyazato, A., Yamamoto, N., Mouri, S., Shibuya, Y., Nakamura, K., Aoyagi, T., Hatta, M., Kunishima, H., Hirakata, Y., Itoh, Y., Kaku, M., and Kawakami, K. (2009). Toll-like receptor 4dependent activation of myeloid dendritic cells by leukocidin of Staphylococcus aureus. Microbes Infect. 11, 245-253.

Inoshima, I., Inoshima, N., Wilke, G. A., Powers, M. E., Frank, K. M., Wang, Y., and Wardenburg, J. B. (2011). A Staphylococcus aureus pore-forming toxin subverts the activity of ADAM10 to cause lethal infection in mice. Nat. Med. 17, 1310-1314.

Ira, J., and Johnston, L. J. (2008). Sphingomyelinase generation of ceramide promotes clustering of nanoscale domains in supported bilayer membranes. Biochim. Biophys. Acta 1778, 185-197.

Jarry, T. M., and Cheung, A. L. (2006). Staphylococcus aureus escapes more efficiently from the phagosome of a cystic fibrosis bronchial epithelial cell line than from its normal counterpart. Infect. Immun. 74, 2568-2577.

Jarry, T. M., Memmi, G., and Cheung, A. L. (2008). The expression of alphahemolysin is required for Staphylococcus aureus phagosomal escape after internalization in CFT-1 cells. Cell. Microbiol. 10, 1801-1814.

Joo, H. S., Cheung, G. Y., and Otto, M. (2011). Antimicrobial activity of community-associated methicillinresistant Staphylococcus aureus is caused by phenol-soluble modulin derivatives. J. Biol. Chem. 286, 8933-8940.
Julianelle, J. (1922). Studies of hemolytic staphylococci: hemolytic activity - biochemical reactions serologic reactions. J. Infect. Dis. 31, 256-284.

Kaito, C., Saito, Y., Nagano, G., Ikuo, M., Omae, Y., Hanada, Y., Han, X., Kuwahara-Arai, K., Hishinuma, T., Baba, T., Ito, T., Hiramatsu, K., and Sekimizu, K. (2011). Transcription and translation products of the cytolysin gene psm-mec on the mobile genetic element SCCmec regulate Staphylococcus aureus virulence. PLoS Pathog. 7, e1001267. doi:10.1371/journal.ppat.1001267

Kaneko, J., and Kamio, Y. (2004). Bacterial two-component and hetero-heptameric pore-forming cytolytic toxins: structures, pore-forming mechanism, and organization of the genes. Biosci. Biotechnol. Biochem. 68, 981-1003.

Kaneko, J., Kimura, T., Kawakami, Y., Tomita, T., and Kamio, Y. (1997). Panton-valentine leukocidin genes in a phage-like particle isolated from mitomycin C-treated Staphylococcus aureus V8 (ATCC 49775). Biosci. Biotechnol. Biochem. 61, 1960-1962.

Kielian, T., Cheung, A., and Hickey, W. F. (2001). Diminished virulence of an alpha-toxin mutant of Staphylococcus aureus in experimental brain abscesses. Infect. Immun. 69, 6902-6911.

Kloft, N., Busch, T., Neukirch, C., Weis, S., Boukhallouk, F., Bobkiewicz, W., Cibis, I., Bhakdi, S., and Husmann, M. (2009). Pore-forming toxins activate MAPK p38 by causing loss of cellular potassium. Biochem. Biophys. Res. Commun. 385, 503-506.

Kobayashi, S. D., Malachowa, N., Whitney, A. R., Braughton, K. R., Gardner, D. J., Long, D., Bubeck Wardenburg, J., Schneewind, O., Otto, M., and Deleo, F. R. (2011). Comparative analysis of USA300 virulence determinants in a rabbit model of skin and soft tissue infection. J. Infect. Dis. 204, 937-941.

Konig, B., Koller, M., Prevost, G., Piemont, Y., Alouf, J. E., Schreiner, A., and Konig, W. (1994). Activation of human effector cells by different bacterial toxins (leukocidin, alveolysin, and erythrogenic toxin A): generation of interleukin-8. Infect. Immun. 62, 4831-4837.

Konig, B., Prevost, G., and Konig, W. (1997). Composition of staphylococcal bi-component toxins determines pathophysiological reactions. J. Med. Microbiol. 46, 479-485.

Kreger, A. S., Kim, K. S., Zaboretzky, F., and Bernheimer, A. W.
(1971). Purification and properties of staphylococcal delta hemolysin. Infect. Immun. 3, 449-465.

Kretschmer, D., Gleske, A. K., Rautenberg, M., Wang, R., Koberle, M. Bohn, E., Schoneberg, T., Rabiet, M. J., Boulay, F., Klebanoff, S. J., Van Kessel, K. A., Van Strijp, J. A. Otto, M., and Peschel, A. (2010). Human formyl peptide receptor 2 senses highly pathogenic Staphylococcus aureus. Cell Host Microbe 7 , 463-473.

Krysko, D. V., Agostinis, P., Krysko, O., Garg, A. D., Bachert, C., Lambrecht, B. N., and Vandenabeele, P. (2011). Emerging role of damage-associated molecular patterns derived from mitochondria in inflammation. Trends Immunol. 32, 157-164.

Labandeira-Rey, M., Couzon, F., Boisset, S., Brown, E. L., Bes, M., Benito, Y., Barbu, E. M., Vazquez, V., Hook, M., Etienne, J., Vandenesch, F., and Bowden, M. G. (2007). Staphylococcus aureus Panton-Valentine leukocidin causes necrotizing pneumonia Science 315, 1130-1133.

Lajoie, P., and Nabi, I. R. (2007). Regulation of raft-dependent endocytosis. J. Cell. Mol. Med. 11, 644-653.

Li, M., Diep, B. A., Villaruz, A. E. Braughton, K. R., Jiang, X., Deleo, F. R., Chambers, H. F., Lu, Y., and Otto, M. (2009). Evolution of virulence in epidemic community-associated methicillin-resistant Staphylococcus aureus. Proc. Natl. Acad. Sci. U.S.A. 106, 5883-5888.

Lina, G., Piemont, Y., Godail-Gamot, F., Bes, M., Peter, M. O., Gauduchon, V., Vandenesch, F., and Etienne, J. (1999). Involvement of Panton-Valentine leukocidinproducing Staphylococcus aureus in primary skin infections and pneumonia. Clin. Infect. Dis. 29, 1128-1132.

Lipinska, U., Hermans, K., Meulemans, L., Dumitrescu, O., Badiou, C., Duchateau, L., Haesebrouck, F., Etienne, J., and Lina, G. (2011). Panton-Valentine leukocidin does play a role in the early stage of Staphylococcus aureus skin infections: a rabbit model. PLoS ONE 6, e22864. doi:10.1371/journal.pone. 0022864

Loffler, B., Hussain, M., Grundmeier, M., Bruck, M., Holzinger, D. Varga, G., Roth, J., Kahl, B. C., Proctor, R. A., and Peters, G. (2010). Staphylococcus aureus pantonvalentine leukocidin is a very potent cytotoxic factor for human neutrophils. PLoS Pathog. 6, el000715. doi:10.1371/journal.ppat.1000715
Marchand, A., Verdon, J., Lacombe, C., Crapart, S., Hechard, Y., and Berjeaud, J. M. (2011). AntiLegionella activity of staphylococcal hemolytic peptides. Peptides 32, 845-851.

Mariathasan, S., Weiss, D. S., Newton, K., Mcbride, J., O'Rourke, K. Roose-Girma, M., Lee, W. P., Weinrauch, Y., Monack, D. M., and Dixit, V. M. (2006). Cryopyrin activates the inflammasome in response to toxins and ATP. Nature 440, 228-232.

Martinon, F. (2010). Signaling by ROS drives inflammasome activation. Eur. J. Immunol. 40, 616-619.

Mehlin, C., Headley, C. M., and Klebanoff, S. J. (1999). An inflammatory polypeptide complex from Staphylococcus epidermidis: isolation and characterization. J. Exp. Med. 189, 907-918.

Menestrina, G. (1986). Ionic channels formed by Staphylococcus aureus alpha-toxin: voltage-dependent inhibition by divalent and trivalent cations. J. Membr. Biol. 90, 177-190.

Meyer, F., Girardot, R., Piemont, Y., Prevost, G., and Colin, D. A. (2009). Analysis of the specificity of PantonValentine leucocidin and gammahemolysin F component binding. Infect. Immun. 77, 266-273.

Miller, L. S., Pietras, E. M., Uricchio, L. H., Hirano, K., Rao, S., Lin, H. O'Connell, R. M., Iwakura, Y., Cheung, A. L., Cheng, G., and Modlin, R. L. (2007). Inflammasomemediated production of IL-1beta is required for neutrophil recruitment against Staphylococcus aureus in vivo. J. Immunol. 179, 6933-6942.

Monecke, S., Kuhnert, P., Hotzel, H., Slickers, P., and Ehricht, R. (2007). Microarray based study on virulence-associated genes and resistance determinants of Staphylococcus aureus isolates from cattle. Vet. Microbiol. 125, 128-140.

Morinaga, N., Kaihou, Y., and Noda, M. (2003). Purification, cloning and characterization of variant LukE-LukD with strong leukocidal activity of staphylococcal bi-component leukotoxin family. Microbiol. Immunol. 47, 81-90.

Narita, S., Kaneko, J., Chiba, J., Piemont, Y., Jarraud, S., Etienne, J., and Kamio, Y. (2001). Phage conversion of Panton-Valentine leukocidin in Staphylococcus aureus: molecular analysis of a PVL-converting phage, phiSLT. Gene 268, 195-206.

Noda, M., Kato, I., Hirayama, T., and Matsuda, F. (1980). Fixation and inactivation of staphylococcal leukocidin by phosphatidylcholine and 
ganglioside GM1 in rabbit polymorphonuclear leukocytes. Infect. Immun. 29, 678-684.

Olson, R., Nariya, H., Yokota, K., Kamio, Y., and Gouaux, E. (1999). Crystal structure of staphylococcal LukF delineates conformational changes accompanying formation of a transmembrane channel. Nat. Struct. Biol. 6, 134-140.

Otto, M. (2010). Basis of virulence in community-associated methicillinresistant Staphylococcus aureus. Annu. Rev. Microbiol. 64, 143-162.

Panton, P. N., and Valentine, F. C. O. (1932). Staphylococcal toxin. Lancet 219, 506-508.

Pany, S., Vijayvargia, R., and Krishnasastry, M. V. (2004). Caveolin-1 binding motif of alpha-hemolysin: its role in stability and pore formation. Biochem. Biophys. Res. Commun. 322, 29-36.

Pedelacq, J. D., Maveyraud, L., Prevost, G., Baba-Moussa, L., Gonzalez, A., Courcelle, E., Shepard, W., Monteil, H., Samama, J. P., and Mourey, L. (1999). The structure of a Staphylococcus aureus leucocidin component (LukF-PV) reveals the fold of the water-soluble species of a family of transmembrane pore-forming toxins. Structure 7, 277-287.

Perret, M., Badiou, C., Lina, G., Burbaud, S., Benito, Y., Bes, M., Cottin, V., Couzon, F., Juruj, C., Dauwalder, O., Goutagny, N., An Diep, B., Vandenesch, F., and Henry, T. (in press). Cross-talk between S. aureus leukocidins-intoxicated macrophages and lung epithelial cells triggers chemokine secretion in an inflammasome-dependent manner. Cell. Microbiol.

Peyrani, P., Allen, M., Wiemken, T. L., Haque, N. Z., Zervos, M. J., Ford, K. D., Scerpella, E. G., Mangino, J. E., Kett, D. H., and Ramirez, J. A. (2011). Severity of disease and clinical outcomes in patients with hospital-acquired pneumonia due to methicillin-resistant Staphylococcus aureus strains not influenced by the presence of the panton-valentine leukocidin gene. Clin. Infect. Dis. 53, 766-771.

Plouin-Gaudon, I., Clement, S., Huggler, E., Chaponnier, C., Francois, P., Lew, D., Schrenzel, J., Vaudaux, P., and Lacroix, J. S. (2006). Intracellular residency is frequently associated with recurrent Staphylococcus aureus rhinosinusitis. Rhinology 44, 249-254.

Queck, S. Y., Khan, B. A., Wang, R., Bach, T. H., Kretschmer, D., Chen, L., Kreiswirth, B. N., Peschel,
A., Deleo, F. R., and Otto, M. (2009). Mobile genetic elementencoded cytolysin connects virulence to methicillin resistance in MRSA. PLoS Pathog. 5, e1000533. doi:10.1371/journal.ppat.1000533

Rasigade, J. P., Sicot, N., Laurent, F., Lina, G., Vandenesch, F., and Etienne, J. (2011). A history of Panton-Valentine leukocidin (PVL)associated infection protects against death in PVL-associated pneumonia. Vaccine 29, 4185-4186.

Ratner, A. J., Hippe, K. R., Aguilar, J. L., Bender, M. H., Nelson, A. L., and Weiser, J. N. (2006). Epithelial cells are sensitive detectors of bacterial pore-forming toxins. J. Biol. Chem. 281, 12994-12998.

Rautenberg, M., Joo, H. S., Otto, M., and Peschel, A. (2011). Neutrophil responses to staphylococcal pathogens and commensals via the formyl peptide receptor 2 relates to phenol-soluble modulin release and virulence. FASEB J. 25, 1254-1263.

Rose, F., Dahlem, G., Guthmann, B., Grimminger, F., Maus, U., Hanze, J., Duemmer, N., Grandel, U., Seeger, W., and Ghofrani, H. A. (2002). Mediator generation and signaling events in alveolar epithelial cells attacked by $S$. aureus alpha-toxin. Am. J. Physiol. Lung Cell. Mol. Physiol. 282, L207-L214.

Shallcross, L. J., Williams, K., Hopkins, S., Aldridge, R. W., Johnson, A. M., and Hayward, A. C. (2010). Panton-Valentine leukocidin associated staphylococcal disease: a crosssectional study at a London hospital, England. Clin. Microbiol. Infect. 16, 1644-1648.

Shukla, S. K., Karow, M. E., Brady, J. M., Stemper, M. E., Kislow, J., Moore, N., Wroblewski, K., Chyou, P. H., Warshauer, D. M., Reed, K. D., Lynfield, R., and Schwan, W. R. (2010). Virulence genes and genotypic associations in nasal carriage, community-associated methicillinsusceptible and methicillin-resistant USA400 Staphylococcus aureus isolates. J. Clin. Microbiol. 48, 3582-3592.

Song, L., Hobaugh, M. R., Shustak, C., Cheley, S., Bayley, H., and Gouaux, J. E. (1996). Structure of staphylococcal alpha-hemolysin, a heptameric transmembrane pore. Science 274, 1859-1866.

Supersac, G., Piemont, Y., Kubina, M., Prevost, G., and Foster, T. J. (1998). Assessment of the role of gamma-toxin in experimental endophthalmitis using a hlgdeficient mutant of Staphylococcus aureus. Microb. Pathog. 24, 241-251.
Suttorp, N., and Habben, E. (1988). Effect of staphylococcal alpha-toxin on intracellular $\mathrm{Ca} 2+$ in polymorphonuclear leukocytes. Infect. Immun. 56, 2228-2234.

Suttorp, N., Seeger, W., ZuckerReimann, J., Roka, L., and Bhakdi, S. (1987). Mechanism of leukotriene generation in polymorphonuclear leukocytes by staphylococcal alpha-toxin. Infect. Immun. 55, 104-110.

Tajima, A., Iwase, T., Shinji, H., Seki, K., and Mizunoe, Y. (2009). Inhibition of endothelial interleukin-8 production and neutrophil transmigration by Staphylococcus aureu beta-hemolysin. Infect. Immun. 77, 327-334.

Teijaro, J. R., Walsh, K. B., Cahalan, S., Fremgen, D. M., Roberts, E., Scott, F., Martinborough, E., Peach, R., Oldstone, M. B., and Rosen, H. (2011). Endothelial cells are central orchestrators of cytokine amplification during influenza virus infection. Cell 146, 980-991.

Thelestam, M., Mollby, R., and Wadstrom, T. (1973). Effects of staphylococcal alpha-, beta-, delta-, and gamma-hemolysins on human diploid fibroblasts and HeLa cells: evaluation of a new quantitative as say for measuring cell damage. Infect. Immun. 8, 938-946.

Tristan, A., Benito, Y., Montserret, R., Boisset, S., Dusserre, E., Penin, F., Ruggiero, F., Etienne, J., LortatJacob, H., Lina, G., Bowden, M G., and Vandenesch, F. (2009). The signal peptide of Staphylococcus aureus panton valentine leukocidin LukS component mediates increased adhesion to heparan sulfates. PLoS ONE 4, e5042. doi:10.1371/journal.pone. 0005042

Tristan, A., Bes, M., Meugnier, H., Lina, G., Bozdogan, B., Courvalin, P., Reverdy, M. E., Enright, M. C., Vandenesch, F., and Etienne, J. (2007). Global distribution of Panton-Valentine leukocidin - positive methicillin-resistant Staphylococcus aureus, 2006. Emerging Infect. Dis. 13, 594-600.

Tseng, C. W., Kyme, P., Low, J., Rocha, M. A., Alsabeh, R., Miller, L. G., Otto, M., Arditi, M., Diep, B. A., Nizet, V., Doherty, T. M., Beenhouwer, D. O. and Liu, G. Y. (2009). Staphylococcus aureus Panton-Valentine leukocidin contributes to inflammation and muscle tissue injury. PLoS ONE 4, e6387. doi:10.1371/journal.pone. 0006387

Tunggal, J. A., Helfrich, I., Schmitz, A., Schwarz, H., Gunzel, D., Fromm, M., Kemler, R., Krieg, T., and Niessen, C.
M. (2005). E-cadherin is essential for in vivo epidermal barrier function by regulating tight junctions. $E M B O \mathrm{~J}$. 24, 1146-1156.

Valeva, A., Hellmann, N., Walev, I., Strand, D., Plate, M., Boukhallouk, F., Brack, A., Hanada, K., Decker, H., and Bhakdi, S. (2006). Evidence that clustered phosphocholine head groups serve as sites for binding and assembly of an oligomeric protein pore. J. Biol. Chem. 281, 26014-26021.

Valeva, A., Walev, I., Pinkernell, M., Walker, B., Bayley, H., Palmer, M., and Bhakdi, S. (1997). Transmembrane beta-barrel of staphylococcal alpha-toxin forms in sensitive but not in resistant cells. Proc. Natl. Acad. Sci. U.S.A. 94, 11607-11611.

van Wamel, W. J., Rooijakkers, S. H., Ruyken, M., Van Kessel, K. P., and Van Strijp, J. A. (2006). The innate immune modulators staphylococcal complement inhibitor and chemotaxis inhibitory protein of Staphylococcus aureus are located on beta-hemolysin-converting bacteriophages. J. Bacteriol. 188, 1310-1315.

Vandanmagsar, B., Youm, Y. H., Ravussin, A., Galgani, J. E., Stadler, K., Mynatt, R. L., Ravussin, E., Stephens, J. M., and Dixit, V. D. (2011). The NLRP3 inflammasome instigates obesity-induced inflammation and insulin resistance. Nat. Med. 17, 179-188.

Vandenesch, F., Couzon, F., Boisset, S., Benito, Y., Brown, E. L., Lina, G., Etienne, J., and Bowden, M. G. (2010). The Panton-Valentine leukocidin is a virulence factor in a murine model of necrotizing pneumonia. J. Infect. Dis. 201, 967-969.

Vandenesch, F., Naimi, T., Enright, M. C., Lina, G., Nimmo, G. R., Heffernan, H., Liassine, N., Bes, M., Greenland, T., Reverdy, M. E., and Etienne, J. (2003). Communityacquired methicillin-resistant Staphylococcus aureus carrying Panton-Valentine leukocidin genes: worldwide emergence. Emerging Infect. Dis. 9, 978-984.

Vasil, M. L., Stonehouse, M. J., Vasil, A. I., Wadsworth, S. J., Goldfine, H., Bolcome, R. E. III, and Chan, J. (2009). A complex extracellular sphingomyelinase of Pseudomonas aeruginosa inhibits angiogenesis by selective cytotoxicity to endothelial cells. PLoS Pathog. 5, e1000420. doi:10.1371/journal.ppat.1000420

Ventura, C. L., Malachowa, N., Hammer, C. H., Nardone, G. A., Robinson, M. A., Kobayashi, S. D., 
and Deleo, F. R. (2010). Identification of a novel Staphylococcus aureus two-component leukotoxin using cell surface proteomics. PLoS ONE 5, el1634. doi:10.1371/journal.pone.0011634

Verdon, J., Girardin, N., Lacombe, C., Berjeaud, J. M., and Hechard, Y. (2009). delta-hemolysin, an update on a membrane-interacting peptide. Peptides 30, 817-823.

Verkaik, N. J., Dauwalder, O., Antri, K., Boubekri, I., De Vogel, C. P., Badiou, C., Bes, M., Vandenesch, F., Tazir, M., Hooijkaas, H., Verbrugh, H. A., Van Belkum, A., Etienne, J., Lina, G., Ramdani-Bouguessa, N., and Van Wamel, W. J. (2010). Immunogenicity of toxins during Staphylococcus aureus infection. Clin. Infect. Dis. 50, 61-68.

Vojtov, N., Ross, H. F., and Novick, R. P. (2002). Global repression of exotoxin synthesis by staphylococcal superantigens. Proc. Natl. Acad. Sci. U.S.A. 99, 10102-10107.

Walev, I., Martin, E., Jonas, D., Mohamadzadeh, M., Muller-Klieser, W., Kunz, L., and Bhakdi, S. (1993). Staphylococcal alpha-toxin kills human keratinocytes by permeabilizing the plasma membrane for monovalent ions. Infect. Immun. 61, 4972-4979.

Walev, I., Weller, U., Strauch, S., Foster, T., and Bhakdi, S. (1996). Selective killing of human monocytes and cytokine release provoked by sphingomyelinase (beta-toxin) of Staphylococcus aureus. Infect. Immun. 64, 2974-2979.

Wang, R., Braughton, K. R., Kretschmer, D., Bach, T. H., Queck, S. Y., Li, M., Kennedy, A. D., Dorward, D. W., Klebanoff, S. J., Peschel, A., Deleo, F. R., and Otto, M. (2007). Identification of novel cytolytic peptides as key virulence determinants for community-associated MRSA. Nat. Med. 13, 1510-1514.

Wang, R., Khan, B. A., Cheung, G. Y., Bach, T. H., Jameson-Lee, M., Kong, K. F., Queck, S. Y., and Otto, M. (2011). Staphylococcus epidermidis surfactant peptides promote biofilm maturation and dissemination of biofilm-associated infection in mice. J. Clin. Invest. 121, 238-248.

Watanabe, M., Tomita, T., and Yasuda, T. (1987). Membrane-damaging action of staphylococcal alpha-toxin on phospholipid-cholesterol liposomes. Biochim. Biophys. Acta 898 257-265.

Wilke, G. A., and Bubeck Wardenburg, J. (2010). Role of a disintegrin and metalloprotease 10 in Staphylococcus aureus alpha-hemolysinmediated cellular injury. Proc. Natl. Acad. Sci. U.S.A. 107, 13473-13478.

Wiseman, G. M. (1975). The hemolysins of Staphylococcus aureus. Bacteriol. Rev. 39, 317-344.

Ziebandt, A. K., Kusch, H., Degner, M. Jaglitz, S., Sibbald, M. J., Arends, J. P., Chlebowicz, M. A., Albrecht, D. Pantucek, R., Doskar, J., Ziebuhr, W. Broker, B. M., Hecker, M., Van Dijl, J. M., and Engelmann, S. (2010). Proteomics uncovers extreme heterogeneity in the Staphylococcus aureus exoproteome due to genomic plasticity and variant gene regulation. Proteomics 10, 1634-1644.

Zivkovic, A., Sharif, O., Stich, K. Doninger, B., Biaggio, M., Colinge, J., Bilban, M., Mesteri, I., Hazemi, P., Lemmens-Gruber, R. and Knapp, S. (2011). TLR 2 and CD14 mediate innate immunity and lung inflammation to staphylococca Panton-Valentine leukocidin in vivo. J. Immunol. 186, 1608-1617.

Conflict of Interest Statement: The authors declare that the research was conducted in the absence of any commercial or financial relationships that could be construed as a potential conflict of interest.

Received: 26 December 2011; paper pending published: 10 January 2012; accepted: 31 January 2012; published online: 16 February 2012.

Citation: Vandenesch F, Lina $G$ and Henry $T$ (2012) Staphylococcus aureus hemolysins, bi-component leukocidins, and cytolytic peptides: a redundant arsenal of membrane-damaging virulence factors? Front. Cell. Inf. Microbio. 2:12. doi: 10.3389/fcimb.2012.00012

Copyright () 2012 Vandenesch, Lina and Henry. This is an open-access article distributed under the terms of the Creative Commons Attribution Non Commercial License, which permits noncommercial use, distribution, and reproduction in other forums, provided the original authors and source are credited. 